\title{
Banking Disclosure Regimes for Regulating Speculative Behavior
}

Financial fragility has been an ever-present attribute of the U.S. econoiny. As one theorist stated, "[f]inancial instability and crises have been prominent features of the American econorny since the beginning of our Republic. The break down of the financial and banking systein of 1929/33 was an extreine form of a recurrent plienoinen[on]." The excessively speculative conduct of economic actors, including banks whicl by tlieir very nature are speculative enterprises, ${ }^{2}$ contributes to

1. First Meeting on the Condition of the Banking System: Hearings Before the Senate Comm. on Banking, Housing and Urban Affairs, 95th Cong., 1st Sess. 356 (1977) (statement of Prof. Hyman Minsky); see A. BuRns, New Facts on Business CyCles 3, 29 (1950) ("For the present, obituaries on the business cycle are romantic expressions of human impatience, not records of solid achievement.... The fear of business cycles which rules our economic thinking is a fear of severe depressions.").

A financial system is "fragile" if its "continued normal functioming can be disrupted by some not unusual event. Systemic fragility means that the development of a fragile financial structure results from the normal functioning of our economy ...." Minsky, A Theory of Systemic Fragility, in Financial CRises 138, 139 (E. Altman \& A. Sametz eds. 1977) (emphasis im original). Chairman Volcker of the Federal Reserve Board has expressed alarm over the " "extraordinary"” increase in debt during the last three years and that " "certain groups of borrowers are already under severe financial stress," " and has concluded that the " 'vulnerability of the economy to unanticipated increases in interest rates or a shortfall in mcome appears to be imcreasing." " Murray, Volcker Warns the Rapid Rise in Debt Is Serious Threat to Economy's Health, Wall St. J., Apr. 24, 1986, at 2, cols. 2-3 (w. ed.) (quoting Chairman Volcker). The Reagan administration's argument that financial markets can judge how much credit to issue, see Murray, Debt-Happy Americans Cause Fed Foreboding, Wall St. J., Apr. 28, 1986, at 1, col. 5 (w. ed.), assumes that presently risk taking is efficient, which is not the case. See infra note 6 (documenting imefficient bank risk taking) and text aceompanying notes $134-40$ (discussing distortions due to government subsidization of bank risk taking).

2. Minsky, supra note 1, at 144 (notimg that banks "typically engage in speculative finance: the term to maturity of their debts is shorter than that of their assets"). Minsky defines a "speculative financing unit" as "having a positive net worth, even though in soine near-term periods cash payment commitments exceed the cash flow from operations." Id. at 143.

Not all speculative conduct is detrimental to society. The credit intermediation function performed by banks dictates their speculative posture. For example, if it were easy for one economic actor to match temporally her eash available for investment with an equal amount another actor desired to borrow, then there would be less need for banks. In actual econonies, such matching of ultimate borrowers and lenders requires a bank which assunnes risks by adopting a speculative posture of a positive book value but a portfoho with some long-term assets and much short-term debt, implying negative eash flows for some periods. This speculative conduct is highly beneficial because it reduces transaction costs and promotes the efficient allocation of capital. See infra notes 9 \& 126.

Another instance of beneficial speculative conduct is the reduction of risk costs when those who can better bear price and quantity risk do so, as is done, for example, with commodity futures. See M. Friedman, In Defense of Destabilizing Speculation, in The Optimum QUantity of Money AND OTHER ESSAYS 285 (1969) (arguing that speculation, whrether viewed as insuring or gambling, does not involve an economic loss because what one person pays, another gains); Hirschleifer, The 
this instability. ${ }^{3}$ Banks inefficiently take risks by holding financial assets whose returns do not fully compensate them for increased portfolio risks. ${ }^{4}$ Despite the need for careful evaluation of borrower-specific risk and return to ensure efficient risk taking, ${ }^{5}$ banks lacking the necessary expertise have entered new credit markets and consequently have suf-

Theory of Speculation Under Alternative Regimes of Markets, 32 J. FIN. 975 (1977) (arguing that speculation is primarily the result of differences of behef, rather than of risk tolerance). The same benefits apply with equal force in the banking sector, where financial futures allow banks to hedge against interest rate fluctuations. M. STIGUM \& R. BRANCH, JR., MANAGING BANK ASSETS AND LIABILITIES 322-58 (1983) (describing futures strategies available for use by banks and their importance for large banks' abilities to quickly restructure assets and liabilities).

3. See infra text accompanying notes 146-51. For exainple, excessive speculation was a contributing cause of the Great Depression. A. BuRNS, supra note 1, at 29-30 (linking Great Depression with the "speculative fever" of not only stock investors but also banks, which lowered their credit standards during the second half of the 1920's). But see M. FriedmaN \& A. SchwartZ, A Monetary History of THE UNITEd STATES 1867-1960, 244-48 (1963) (concluding that there was evidence that U.S. banks in the late 1920's lowered their credit standards for foreign bonds, but lowered standards were not the main cause of the Depression).

4. This implies a definition of efficient risk taking that resembles the premise of stock portfolio theory. Under this theory, investors require compensation based only on the risk-free rate, which compensates for deferred consuinption, and on the market risk premium, which compensates for the asset's nondiversifiable risk, known as systematic or market risk. See R. BREALEY \& S. MYERS, Principles of Corporate Finance 125-30, 147 (2d ed. 1984) (stating that market risks, as opposed to unique risks, are the predominant influence of the return on common stocks); J.O. LIGHT \& W. WhITE, THE FinANCiAL SYSTEM 168-73, 327-29 (1979) (applying portfolio theory to the behavior of investors in the stock market and corporate-bonds market). But see T. CAMPBELL, FinANCIAL INSTITUTIONS, MARKETS, AND ECONOMIC ACTIVITY 106-08 (1982) (discussing portfoho theory's shortcomings, including difficulties with the central concept of the "market portfolio").

While standard stock portfolio theory is a useful analogy, it does not fully describe efficient bank risk taking. Because many bank assets are loans, banks must consider borrower-specific risks to establish efficient returns. First, there is no mechanism like a stock market to set all loan prices and distribute participations so that returns reflect a marketwide assessment of costs from each loan's nondiversifiable risk. Under portfolio theory, a stock's price reflects systematic risk and not unique risk only "[w] hen all investors hold the market portfolio," T. CAMPBELL, supra, at 103, and this condition requires a competitive market, see R. BREALEY \& S. MYERS, supra, at 150. These assumptions are inapplicable to bank lending: banks inust determine efficient returns for loans instead of simply relying on a market pricing mechanism. Second, the borrower-specific terms and conditions of the loan agreement (including the pledged collateral) will affect the value of the loan. Therefore, setting efficient returus on loans requires an analysis of the fundamental risks of particular borrowers and the terms and conditions of the corresponding loan agreement, see J.O. LIGHT \& W. WHITE, supra, at 185-86 (discussing the pricing of private placements), as well as the diversifiability of the default risk, given the lenders' portfolio, see R. BREALEY AND S. MYERS, supra, at 481 (default on risky bonds is more likely during recessions). Unlike stock portfolio theory, both borrower-specific risks and market risks ought to determine the return demanded.

5. One text advises that banks considering "a strategic decision to enter a new line or to expand an existing line of business" do so "only on the basis of a careful evaluation of the risks, as well as the possible rewards, associated with the new venture." M. STIGUM \& R. BRANCH, JR., supra note 2, at 389. "The drawing up and enforcement of strict credit controls is fundamental to the operation of any financial institution." Id. Banks inust also understand the fundamental risks of potential borrowers and the resulting systematic risk added to the banks' portfolios. See supra note 4. 
fered losses. ${ }^{6}$ This inefficient risk taking increases speculative financing and the fragility of the economy. ${ }^{7}$ Indeed, the Federal Reserve Board's recent restrictions on leveraging of risky conduct reflect its concerns over

6. Careful evaluation of risk and return conceivably might not be cost efficient where a bank is considering investing only a small amount of money in a particnlar sector; however, banks have failed to analyze adequately ventures in which they have inade large financial commitments. For example, Chase Manhattan was forced to pay $\$ 160$ million in coupon interest to institutions whose government securities it had lent to Drysdale Securities which had failed. "Chase got into trouble only because it lacked or failed to implement proper credit controls." M. STIGUM \& R. BRANCH, JR., supra note 2 , at 389 .

An important cause of banks' inefficient risk taking is that they follow other banks into seemingly profitable markets without analyzing the risk-adjusted returns and while ignoring the rcality of diminishing returns:

The catch is that, if all big banks ... are scrambling for the same business, they can all do increased amounts of it . . . only by dealing with less-and-less-creditworthy customers. ...

...

A bank should recognize this, but banks, like investors in anything from tulips to common stock, are subject to crowd psychology. When a particular investment becomes a new, hot fad, they feel compelled to get into it.

Id. at 389-90 (attributing banks' loss experience in real estate investment trusts (REITs) and the failure of Penn Square National Bank to this behavior).

For example, mefficient bank risk taking has occurred in foreign lending. One report stated: Competitive pressures may lead banks to override coumtry risk assessments and engage in imprudent lending. Particularly in the early stages of country lending, competitive behavior tends to dominate. This can mean that new money will continue to pour into a country once it is "in vogue," even though signs of economic difficulty may already be evident.

GROUP OF THIRTY, RISKS IN INTERNATIONAL BANK LENDING 9 (1982) (suggesting that some bank lending to Peru, Turkey, and Poland was due to this behavior, but noting that some banks have tried to prevent excess exposure by self-imposed limits on foreign lending). For a discussion of the banking systein's vuhierability to a defanlt by sovereigu borrowers, see infra notes 60-61.

Bank lending to REITs provides more evidence of inefficient risk taking. Despite banks' familiarity with the construction-loan busmess, bank-sponsored REITs had dangeronsly high levels of short-term debt and lacked enough competent inanagers to evaluate proposed constrnction projects. Elebash, Bank REITs: A Continuing Embarrassment, 48 APPRAISAL J. 267, 273 (1980). "Many bankers have acknowledged after the fact that had it not becn for the sponsorship of the 'parent' they would not have made the loans they did. The sponsorship had the ring of the inoral obligation." Stevenson, What Went Wrong with the REITs?, 45 APPRAISAL J. 249, 254 (1977). However, even for nonafiliated REITs, banks "made loans for projects they would never have financed directly, and they permitted some REITs to build a giant pyramid of debt on what was often a thin foundation of equity capital." Robertson, How the Bankers Got Trapped in the REIT Disaster, FORTUNE, Mar. I975, at 113, 113. " 'In financing REITs imitially, it appears that banks made little financial and credit analysis of these loans." " Id. at I69 (quoting Frederick Frey, chief examiner of the N.Y. Fed. Reserve Bank).

Banks also have extended consumer credit at an ambitiously fast paee, and now $\$ 48$ billion of consumer and mortgage debt is past due. "After threc years of wild growth, consumer debt is fast becoming another sinkhole in lenders' credit swamp." McCoy, Loan Morass: Losses on Credit Cards, Other Consumer Debt Are Climbing Rapidly, Wall St. J., Dee. 2, 1985, at 1, col. 6 (w. ed.). Much of the losses from consumer credit can be traced to banks seeking promises of high returns without considering credit risk: "[C]redit has been given where credit isn't due. Bankers have clinbed further and further down the economic ladder in the frenzied search for new customers. Prisoners, unemployed teen-agers, even a few household pets have received credit cards." Id.

This inefficient risk taking is likely to continue and inay worsen because of increasing competitive pressures banks facc, see infra text aecoinpanying note 128 , and governmental subsidization of bank risk taking, see infra text accompanying notes 134-40.

7. See infra text aecompanying notes 148-51. 
excessive risk taking. ${ }^{8}$ This Comment argues that the current regulatory regime, which is premised on a tradition of secrecy and a fear of bank failures, deserves much of the blame for the financial fragility resulting from banks' mefficient risk taking.

The fractional-reserve banking system, wherein banks keep only a fraction of total deposits on hand, is partially responsible for its own instability. Banks perform an intermediation function by matching the needs of borrowers for long-term credit to the desires of lenders for short-term deposits. ${ }^{9}$ If a bank's liquid reserves and highly liquid assets are imsufficient to meet the depositors' demands, a sudden withdrawal of funds by a large number of depositors may cause a liquidity crisis. A bank failure occurs when a bank's assets are insufficient to discharge liabilities owed to depositors. A crisis of confidence in the banking system inay result from a succession of bank failures, causing depositors to fur-

8. E.g., Supplemental Adjusted Capital Measure, 51 Fed. Reg. 3976 (proposed Jan. 31, 1986) (proposing risk-based capital requirements linking capital increases with bank exposure to categories of assets judged to have greater default risks); Purchase of Debt Securities to Finance Corporate Takeovers, 51 Fed. Reg. 1771 (proposed Jan. 15, 1986) (applying margin requirements to highly leveraged debt securities, called "junk bonds," issued in takeover battles). "The Federal Reserve has stated repeatedly that it is concerned about mounting levels of debt among consumers, corporations and governments. Such concern led to its highly disputed action last week to limit the use of highrisk corporate debt imstruments in certain kinds of takeovers." Nash, U.S. Regulators Want Banks To Cover Risky Loans Better, N.Y. Times, Jan. 16, 1986, at 1, col. 1 (nat'l ed.); see Malabre \& Clark, Nagging Worries: As Economy Revives, Analysts Grow Edgier About Old Problems, Wall St. J., Dec. 10,1985 , at 1, col. 6 (w. ed.) (quotimg Paul Samuelson as saying junk bonds in corporate takeovers are "giving junk a bad name").

9. Banks transform ilhquid assets into demand and time deposits, satisfying depositors' demands for investments that provide liquidity options. Diamond \& Dybvig, Bank Runs, Deposit Insurance, and Liquidity, $91 \mathrm{~J}$. PoL. EcoN. 401, 403 (1983). Given that all depositors usually will not want to withdraw their deposits at one time, it is feasible for banks to lend a part of their deposits for lengths of time exceeding the maturity period of the deposits. Banks increase their ability to handle variations in withdrawals of deposits by diversifying their sources of funds and loans and by specializing in this transformation fnnetion. See Tobin, Commercial Banks as Creators of "Money," in BANKING AND MONETARY Studies 408, 410-11 (D. Carson ed. 1963). The use of a specialist intermediary is economically efficient because the bank can reduce the risk costs incurred by ultimate lenders. Id. at 411 . This should reduce the returns required from ultimate borrowers and make some projects financially feasible that had been projected to result in negative returns under the previously higher interest rates.

Some see this credit-intermediation function as "mismatching," e.g., McCulloch, Misintermediation and Macroeconomic Fluctuations, 8 J. MONETARY ECON. 103 (1981) (arguing that this "inisintermediation" would not occnr bnt for government interventions, such as deposit insurance), but the better view is that this transformation of illiquid assets is a major reason for banks' existence, eg., Diamond \& Dybvig, supra, (arguing that this matching provides banks a market at the cost of making them susceptible to runs, but that deposit insurance allows for a stable equilibrium).

Under a fractional-reserve banking system, banks are required to maintain a fraction of deposits as a reserve. For example, if the reserve requirement were $10 \%$, banks would have to retain one dollar for every 10 dollars of deposits. See generally D. Kidwell \& R. Peterson, Financial INSTITUTIONS, MARKETS, AND MONEY 128-52 (1981) (discussing reserve requirements and the deposit-expansion process); Tobin, supra, at 416-18 (arguing that bank reserves are a function of lending opportnnities and interest rates, as well as legal reqnirements). 
ther withdraw funds in a self-fulfilling prophecy capable of depleting the liquidity reserves of even the soundest banks. ${ }^{10}$

The specter of bank runs, bank hohdays, and limits on depositor withdrawals conjures up images of market collapse rather than the accepted "weeding out" of inefficient firms by a well-functioning, competitive market. A counpetitive marketplace, however, entails economic evolution and elimination as some firms introduce new technologies and services and inefficient firms fail, freeing resources for einployment elsewhere. ${ }^{11}$ A behef that banks are "special"12 has led to a regulatory regime which has insulated many banks from these inarket forces and concurrently removed effective inarket discipline of bank risk taking. In contrast, the disclosure regime proposed in this Comment accepts the fact that inefficient banks inust be allowed to fail in an orderly inanner.

A disclosure regime will provide uninsured depositors with the information needed to evaluate more carefully their banks and allocate their funds accordingly. This Comment argues that the current federal regulatory structure, a nondisclosure regime, prevents depositors from obtaining the information necessary to discipline bank risk taking. Part I describes the federal banking regulatory regime and argues that lending risks have becoine the primary cause of bank failures. Part II exphcates a theory of confidence production in commercial banking and attributes the need for government intervention to inarket failure which causes an uuregulated banking systein to produce too hittle confidence. It then argues that the regulatory limit on the availability of information has caused much of the present instability in the banking system. Finally, Part III concludes that a mandated-disclosure regime, as opposed to a regulatory system that perumits banks to choose the level of disclosure, is needed to effectively produce confidence and prevent bank runs.

\section{I}

The NoNDISCLOSURE REgIME FOR REgULATING LENDING RISKS

The U.S. banking system is a dual banking system, coinprising federally chartered banks (national banks) and state chartered banks (state

10. See infra note 122. This potential is inherent in a fractional-reserve banking system, unless banks keep deposits in the form of highly liquid assets. Such an asset-management strategy, however, would undermine banks' important role of credit mtermediation. See supra note 9 and infra text accompanying note 126.

11. See J. Schumpeter, Capitalism, Socialism, ANd Democracy 81-86 (3d ed. 1950).

12. See, e.g., 1982 Federal Reserve Bank MinNeapolis ANnual Report, Are Banks SPECIAL? 7-15 (arguing that three "essential" characteristics distinguish banks from other firms: banks offer transaction accounts, serve as a backup source of liquidity for virtually all other firms, and are the vehicle for transmitting monetary policy) [hereinafter cited as ARE BANKS SPECIAL?]. 
banks). ${ }^{13}$ The Office of Comptroller of the Currency (OCC) is the primary regulator of national banks. ${ }^{14}$ The Federal Reserve Board (Federal Reserve) has regulatory responsibility for all member banks of the Federal Reserve System, and is the primary regulator of the state member banks. ${ }^{15}$ It also regulates bank holding companies ${ }^{16}$ and, under its monetary-control responsibilities, sets the reserve requirements for all banks. ${ }^{17}$ The Federal Deposit Insurance Corporation (FDIC) administers the insurance fund, has regulatory authority over insurance matters for all federally insured state and national banks, and is the primary regulator for insured, state nonmember banks. ${ }^{18}$ Therefore, most state banks are regulated at both the state and federal level, which represents a significant departure from the original conception of a dual banking system. ${ }^{19}$ The examination policies and disclosure requirements for the various federal agencies are coordinated through the Federal Financial Institutions Examination Council (FFIEC). ${ }^{20}$ Finally, the Securities and Exchange Commission (SEC) regulates the disclosure in financial statements distributed to shareholders by bank holding companies. ${ }^{21}$ The focus of this Cominent is primarily on the federal regulation of national banks.

The important role of banks in the economy has encouraged this

13. The National Currency Act, ch. 58, 12 Stat. 665 (1863), which was replaced by the National Bank Act, ch. 106, 13 Stat. 99 (1864), first authorized national banks. For an overview of the dual banking system, see E. SYMONS, JR. \& J. WHITE, BANk1NG LAW 69-70 (2d ed. 1984).

The savings and loan (S\&L) industry is also composed of federally chartered and statechartered institutions. The Federal Home Loan Bank Board (FHLBB) is the federal regulator and the Federal Savings and Loan Insurance Corporation (FSLIC) administers the federal deposit insurance fund for S\&Ls.

14. Id. at 70. National banks also are members of the Federal Reserve System and are required to have federal deposit insurance. $I d$.

15. Task Group on Regulation of Financial Services, Blueprint for Reform 18 (1984) [hereinafter cited as BLUEPRINT]. State member banks are state-chartered banks that are members of the Federal Reserve System. 12 U.S.C. $\$ 1813$ (b) (1982).

16. 12 U.S.C. $\S 1844$ (1982); BLUEPRINT, supra note 15 , at 20.

17. 12 U.S.C. $\$ 461$ (1982).

18. BLUEPRINT, supra note 15 , at 18 .

19. Some have argued that the federal regulations are so pervasive that the banking system no longer can be aceurately characterized as a dual banking system. See, e.g., Wille, State Banking: $A$ Study in Dual Regulation, 31 LAW \& CoNTEMP. ProBs. 733, 735-43, 747 (1966) ("Despite verbal commitunent to a dual system of regulation, the actions of Congress and the federal bank agencies reflect considerable reluctance to grant the states any additional responsibilities and an equal readimess to impose ever nore federal control and direction over state-chartered institutions." Id. at 747). For an arguinent that there are political benefits in inaintaining a dual banking system in order to pit state and national banks against each other and thereby check and balance the "extraordinary political power" of banks, see Havighurst, Banking, Part I: Banking Regulation-Foreword, 31 LAW \& CONTEMP. Probs. 635, 637-38 (1966).

20. 12 U.S.C. $\$ 3301$ (1982). The OCC, FDIC, Federal Reserve, FHLBB, and National Credit Union Administration are inembers of the FFIEC. 12 U.S.C. $\$ 3302$ (1982).

21. 17 C.F.R. $\$ 210.9-01$ to -07 (1985). The issuance of securities by a bank is regulated by the bank's primary federal regulator. 15 U.S.C. $\$ 781(i)$ (1982). 
intertwining of banking regulatory authorities. ${ }^{22}$ The Bush Task Force

Report stresses the importance of a stable banking systein:

Without question, stability of the financial system is a paramount goal of financial regulation. ...

Probably no single area is as central to guaranteemg a stable financial system as the integrity and soundness of the U.S. banking system. Banks hold by far the largest portion of private financial assets, and they also have an important role in both the payments system and the transmission of monetary pohicy. ${ }^{23}$

Banks also function as a backup source of hquidity for virtually all other firms by, for exainple, extending loans and letters of credit. ${ }^{24}$ Econoinic recessions and contractions of the inoney supply have often been associated with widespread bank failures. ${ }^{25}$

In part to counter the threat of bank runs and econoinic collapse, the federal banking regulatory regime is unique among administrative agencies in that it "ha[s] long inaintained systeins of secret evidence, secret law, and secret pohicy."26 The traditional wisdon, $\mathrm{n} 1$ the words of a former Chief Counsel of the OCC, was that "[a]nything that sniacked of controversy was considered bad for the banking 'in1age." "27 The

22. See, e.g., T. CAMPBELL, supra note 4, at 381 (1982) ("The prospect of a significant collapse of financial markets has been the prime mover behind regulation of financial markets in the Umited States for over 150 years.").

23. BluePrint, supra note 15 , at $34-35$; see supra note 12 ; see also $T$. CAMPBELL, supra note 4 , at 445 . As of the end of 1983 , commercial banks held over $\$ 2.3$ trillion in financial assets. BLUEPRINT, supra note 15, at 20.

24. ARE BANKS SPECIAL?, supra note 12, at 9-11.

25. See infra note 125 .

26. Davis, Administrative Procedure in the Regulation of Banking, 31 LAW \& CONTEMP. Probs. 713, 713 (1966) (criticizing excessive secrecy in OCC's decisions to charter banks and approve branches); see, e.g., Administrative Procedure Act: Hearings on S. 1663 Before the Subcomm. on Administrative Practice and Procedure of the Senate Comm. on the Judiciary, 88th Cong., 2d Sess. 418-19 (1964) (letter of Joseph McMurray, Chairman, FHLBB) (noting the "recognition of the frequent need for confidential investigations and information" as "the historic difference in treatinent between adininistrative activity in the financial field and the same activity in areas within the purview of, for example, the Interstate Commerce Commission or the Federal Trade Coinmission") [hereinafter cited as $A P A$ Hearings]. One congressional monograph on administrative agencies concluded:

The nature of banking and the public interest in banks shape the proeedural aspects of bank supervision in forms different from those encountered in other branches of administrative regulation. By reason of the fact that few banks operating at a profit can, upon demand, pay off [their] depositors iu eash, there has been traditionally a policy of withholding from the public all information which, either with or without justification, inight provoke a depositors' run on the bank. . . . As a corollary, the exercise of supervisory powers over banks has traditionally been attended by a secrecy antithetical to the publicity which marks most regulatory activities.

S. Doc. No. 186, 76th Cong., 3d Sess. 42-43 (1940-41) (Monograph No. 13).

27. Blooin, Hearing Procedures of the Office of the Comptroller of the Currency, $31 \mathrm{LAw} \&$ Contemp. ProBs. 723, 723 (1966). The author described the traditional secrecy surrounding applications for charters, branches, and mergers:

Alinost every piece of paper pertaining to an application was considered secret, and virtually no public announcements of any kind emauated from the [Comptroller's] Office. 
revered role of secrecy rests primarily on the need to prevent the loss of depositor confidence, as well as to protect privacy and encourage the cooperation of banks with regulators. ${ }^{28}$ Congress followed this policy of secrecy in exeinpting froin the inandatory disclosure provisions of the Freedoin of Information Act (FOIA) matters "contained in or related to examination, operating or condition reports" of financial institutions. ${ }^{29}$ The courts have also subscribed to this traditional wisdom. ${ }^{30}$

The federal regulatory oversight of lending risks can be described as a nondisclosure regime. Although many aspects of banking regulation

\footnotetext{
In the preceding ninety-eight-year history of the Office, there had never been a public hearing or a written opinion published on an application. ... .

In fairness ...., we hasten to state that these methods are the traditionally accepted ones for a bank supervisory agency.
} Id.

28. For a discussion and criticism of these concerns, see infra text accompanying notes 221-53.

29. Freedom of Information Act, 5 U.S.C. $\$$ 552(b)(8) (1982) (exemption 8). Exemption 8 has been incorporated in the regulations of the federal banking agencies. 12 C.F.R. $\$ 4.16(\mathrm{~b})(8)$ (1986) (OCC provision); 12 C.F.R. $\$ 261.6(a)(2)$ (1986) (Federal Reserve provision); 12 C.F.R. $\S 309.5$ (c)(8) (1986) (FDIC provision).

Congress intended exemption 8 to continue this tradition of secrecy in banking regulation, despite the FOIA's general command that the public have access to information on government operations. The Senate report presupposes a nondisclosure regime: "Exemption No. 8 is directed specifically to insuring the security of our financial institutions by making available only to the Government agencies reponsible for the regulation or supervision of such institutions the examination, operating, or condition reports ..." S. REP. No. 813, 89th Cong., 1st Sess. 10 (1965). The House report states that "[t]his exemption is desigued to insure the security and integrity of financial institutions, for the sensitive details collected by Government agencies which regulate these institutions could, if indiscriminately disclosed, cause great harm." H.R. REP. No. 1497, 89th Cong., 2d Sess. 11, reprinted in 1966 U.S. CoDE CONG. \& AD. NEws 2418, 2428; see Note, Freedom of Information: The Statute and the Regulations, 56 GEo. L.J. 18, 50 (1967) (arguing that given the exemption for "commercial and financial information," 5 U.S.C. $\S 552(\mathrm{~b})(4)$, exemption 8 is "superfluous" and Congress kept it in merely "to emphasize congressional intent to protect such material" from disclosure).

For a discussion of the imconsistency of exemption 8 with the purposes of the FOIA, see infra notes 219-20 and aceompanying text.

30. See, e.g., Gregory v. FDIC, 631 F.2d 896, 898-99 (D.C. Cir. 1980) (per curiam) (holding financial reports of closed institutions exempt from disclosure) ("Congress looked to the nature and source of the material and determined to provide absolute protection regardless of the circumstances underlying the regulatory agency's reeeipt or preparation of examination, operating or condition reports."); Consumers Union v. Heimann, 589 F.2d 531, 534 (D.C. Cir. 1978) (holding exemption 8 covers documents concerning bank compliance with Truth-in-Lending Act) ("the primary reason for adoption of exemption 8 was to ensure the security of financial institutions" (footnote omitted)); Webster Groves Trust Co. v. Saxon, 370 F.2d 381, 385 (8th Cir. 1966) (holding formal adversary hearing not required for granting bank charter) ("There is the further factor present that if bank applicants were subjected to severe public cross-examination, public presentation of unfavorable evidence and were forced to disclose their future plans and programs to competitors, public confidence in the banking system could be adversely affected."); Bridgeport Fed. Sav. \& Loan Ass'n v. FHLBB, 307 F.2d 580, 583 (3d Cir. 1962) (holding agency need not disclose information used in approval of branch) ("The use and non-disclosure of confidential information is common practice in the banking field and has been so recoguized and sanctioned by Congress."). But see Consumers Union, 589 F.2d at 541 (Wright, C.J., concurring) (noting that the "long-standing tradition of confidentiality" was referred to with "some reverence" in Congressional testimony, and suggesting that though "some change [in exemption 8] is necessary," it must come from Congress). 
are no longer kept secret, ${ }^{31}$ the regulation of lending risks remains an area shrouded in secrecy. ${ }^{32}$ This resistance to disclosing lendimg risks is due to the close relationship between a bank's soundness and the quahty of its loan portfolio. The nondisclosure regime for regulating lending risks utilizes three types of regulatory tools: (1) regulatory controls over bank managerial discretion, (2) periodic bank examinations, and (3) mandated disclosure to regulators and, to a significantly lesser degree, to the public.

Legal restrictions sucli as lendimg limits, capital ratios, and bad-debt reserves require some diversification of credit risks and the maintenance of resources to absorb losses that may occur. ${ }^{33}$ The federal statutory lending limit ${ }^{34}$ traditionally has served as a crude restraint on managerial imprudence by limiting the amount of not-fully-secured funds a bank may lend to an individual borrower to fifteen percent of the bank's unimpaired capital and surplus. ${ }^{35}$ The recently increased minimum capital reserve requires banks to maintaim capital against which loan losses can be charged. ${ }^{36}$ Banks must also estabhish accounts for the Allowance

31. See, e.g., Bloom, supra note 27, at 724-26 (describing measures to open up OCC's decisions on applications for charters, branches, and mergers); Davis, Banking Agencies' Secrecy: A Response to Mr. Bloom, 31 LAw \& CoNTEMP. ProBs. 731, 731-32 (1966) ("applauding" Comptroller's move away from secrecy in chartering and branching decisions).

32. See infra text accompanying notes 76-77.

33. BLUEPRINT, supra note 15 , at 35-36.

34. 12 U.S.C. $\$ 84$ (1982). There is no legislative history available to discern Congress's intent in 1863 in establishing a federal statutory lending limit. Note, The Propriety of Benefit-Spreading Regulations Under the 10\% Lending Limit of the National Bank Act, 78 Mich. L. REV. 1153, 1157 (1980). However, six days after passage of the McFadden Banking Act of 1927, which amended the lending limit, Representative McFadden stated that the lending limit served the dual purposes of promoting benefit spreading and risk reduction. Id. at 1161-62; see 12 C.F.R. $\S 32.1$ (b) (1986). It is not clear whether Congress intended the lending limit to serve a benefit-spreading objective. Compare Note, supra, at 1155-64 (arguing that the legislature did), with Rappaport, R.S. 5200: Flushing the Piltdown Man Syndrome, 92 Banking L.J. 956, 957-60, 973 (1975) (arguing that the lending limit was modeled after state laws, which had the purpose of benefit spreading, and that its purpose was not originally risk control).

35. Under certain conditions, loans to a borrower may exceed the $15 \%$ limit. 12 U.S.C. $\S 84(\mathrm{c})$ (1982). For a detailed discussion of the lending limit and its application to various transactions, see Glidden, National Bank Lending Limits and the Comptroller's Regs: $A$ Clarification (pt. 1), National Bank Lending Limits: Interpretative Issues and Practical Considerations (pt. 2), 101 BANKING L.J. 430, 554 (1984).

In the foreigu-lending context, application of the lending limit has not been straightforward. It is now settled that foreign governments are "persons" for lending-limit purposes, 12 U.S.C. $\$ 84(a)$ (1982), but a foreigu government's lending limit does not autoinatically apply to its independently operated instrumentalities, such as a public utility. The means and purpose tests, 12 C.F.R. $\S 32.5$ (d) (1986), prevent aggregation of these loans where the public entity has a separate means of repayment of the loans and the purpose of the loan is to further the borrower's separate activities. See Cohen, U.S. Regulation of Bank Lending to LDCs: Balancing Bank Overexposure and Credit Undersupply, 8 YAlE J. WORLD PUB. ORD. 200, 204 n.20, 220-21 (1982) (documenting the extent of U.S. banks' exposure to foreigu debtors and attributing this in part to the ineffectiveness of the lending limit and the means and purpose tests).

36. E.g., 12 C.F.R. $\S 3.6$ (1986) (OCC provision) (requiring minimum total capital of $6 \%$ and 
for Possible Loan Losses (APLL) ${ }^{37}$ and the Allocated Transfer Risk Reserve (ATRR). ${ }^{38}$ These funds are reserves which banks set aside to charge-off losses due to credit risks and foreign-currency exchange problems, respectively.

Regnlators enforce these controls during periodic bank examinations. ${ }^{39}$ Bank examiners review the assets of banks and classify problematic loans by their risk of default. ${ }^{40}$ On the basis of the examination, the OCC may require banks to write off those loans that are classified as "losses" and to increase their reserves to cover possible future losses. The OCC will often enter into agreeinents with individual banks requiring them to increase their capital where asset quahity and other risks indicate that it may be inadequate. When reviewing foreign loans, federal bank examiners use the evaluations of foreign lending risks by the Interagency Country Exposure Review Committee (ICERC). ${ }^{41}$ These evaluations are then transmitted to the banks via the examiners' comments on loans. The results of bank examinations are confidential, ${ }^{42}$ with public disclosure giving rise to criminal penalties. ${ }^{43}$

Quarterly and annual disclosure to regnlators supplements the lending restrictions and examination process as a third regulatory tool. Banks prepare quarterly Consolidated Reports on Condition and Incoine, known as Call Reports, which contain information on deposit

primary capital of $5.5 \%$ ). The futility of relying on capital requirements without adequate disclosure and depositor discipline is discussed infra at text accompanying notes 159-168.

37. See, e.g., 12 C.F.R. $\$ \S 11.919(\mathrm{~b}), .931$ note 4(d), .933 schedule V (1986) (OCC provisions).

38. E.g., 12 C.F.R. $\$ 20.8$ (1986) (OCC provision). For a discussion of the ATRR and the disclosure requirements applicable to it, see Coombe \& Lapic, Problem Loans, Foreign Outstandings, and Other Developments in Bank Disclosure, 40 Bus. LAw. 485, 500-02 (1985).

39. In the future, timing of these examinations will be less calendar-based and nore risk-based. OCC, Bank Supervision Newsletter, Dec. 1984, at 1 (on file with author). The OCC is also beginning to einphasize off-site analysis, such as daily monitoring of certain key statistics, as a suppleinent to this examination policy. Id. at 1-2.

40. Bank examiners use four categories to classify criticized loans: (1) Other Assets Especially Mentioned (OAEM) ("currently protected but ... potentially weak"), (2) Substandard Assets ("inadequately protected by the current sound worth and paying capacity of the obligor or of the collateral pledged"), (3) Doubtful Assets ("all the weaknesses inherent in one classified substandard with the added characteristic that the weaknesses make collection or liquidation in full . . . highly questionable and improbable" but "because of certain inportant and reasonably specific pending factors which may work to the advantage and strengthening of the asset, its classification as an estimated loss is deferred"), and (4) Loss Assets ("uncollectible and of such little value that their continuance as bankable assets is not warranted"). COMPTRoller OF THE CURRENCY, COMPTROLLER'S HANDBOOK FOR NATIONAL BANK EXAMINERS $\$ 215.1$ (Aug. 1984) (coininercial and international binder) [hereinafter cited as COMPTROLLER's HANDBOoK].

41. Cohen, supra note 35, at 213-19 (discussing ICERC and concluding that it able to assess country risk, yet incapable of deterring excessive lending).

42. E.g., 12 C.F.R. $\$ 4.18$ (c) (1986) (OCC provision) ("Under no circumstances shall the bank ... inake public or disclose in any manner the report of examination or any portion of the contents thercof to any person or organization not officially connected with the bank ....")

43. 18 U.S.C. $\S 641$ (1982); 12 C.F.R. $§ 4.18$ (c) (1986) (OCC provision). 
liabilities and nonperforming loans. ${ }^{44}$ Banks also disclose to regulators information concerning loans to foreign countries in the Country Exposure Information Report. ${ }^{45}$

Some of the information banks disclose to regulators is released to the public. Federal regulations require banks to publish parts of the Call Reports, including data on debt more than ninety days past due, nonaccrual debt, and renegotiated loans. ${ }^{46}$ Otlier information, such as data on loans between thirty and eighty-nine days past due, is kept confidential. ${ }^{47}$ Banks inust publicly disclose the amount of imsider loans. ${ }^{48}$

As for bank holding companies, the SEC requires thent to make certain public disclosures through financial statements sent to shareholders: (1) nonaccrual, past due and restructured loans, (2) potential problem loans, (3) foreign outstandings, and (4) loan concentrations by industry. ${ }^{49}$ A significant difference between the SEC and FFIEC disclosure requireinents is the former's provision for disclosure of "potential problem loans." These are loans "not reported as 'nonaccrual, past due or restructured,' but where known information causes inanagement to lave serious doubts as to the ability of the borrowers to comply with the present loan repayment terms." 50 The SEC also requires bank lolding contpanies to identify industries in which their loan concentrations exceed ten percent of the banks' total loans. ${ }^{51}$ In the foreign lending area, the SEC requires banks to disclose publicly, on a country-by-country basis, the name of the country and the amount of loaned funds, where they exceed one percent of total assets. ${ }^{52}$

44. See Coombe \& Lapic, supra note 38 , at $491 \&$ n.27. This requirement applies to all federally supervised banks. The FFIEC has the responsibility to establislı uniform reporting forms and requirements. 12 U.S.C. $\$ 3305$ (a), (c) (1982).

45. In this report, a bank lists those countries where its exposure exceeds the lesser of .75\% of its assets or $15 \%$ of its primary capital. For those countries where a bank's assets exceed $1 \%$ of its total assets or $20 \%$ of its primary capital, the bank must disclose (1) its total exposure to tlie country after adjustments, (2) the breakdown of loans among banks, public sector entities, and otliers, and (3) the breakdown between loans maturing within one year and more than a year. See Coombe \& Lapic, supra note 38 , at 496.

46. These categories and reporting requirements are explained in Cooinbe \& Lapic, supra note 38 , at $491-94$.

47. Id. at 494.

48. See, e.g., 12 C.F.R. $\S 11.844$ (a) (1986) (OCC provision).

49. Amendments to Guide 3, 48 Fed. Reg. 37,609 (1983) (to be codified at 17 C.F.R. pt. 231). Bank loolding companies fall under the requirements, if they liave filed a registration statement for public offerings or have assets and sliareliolder numbers exceeding a minimum level. Coombe \& Lapic, supra note 38, at 502 n.87. This disclosure includes information on assets, liabilities, sliareliolders' equity, loan portfolio, loan losses, and deposits. Id. at 503.

50. Amendments to Guide 3, 48 Fed. Reg. at 37,610 (indicating that this category may not be large, since these loans are often put on nonacerual status). Transfer risk problems are excluded from consideration under this category, but are included in foreign lending disclosure.

51. Id. at 37,612 .

52. Id. at 37,611 . Banks must publicly disclose the names of those countries in whicl1 outstanding loans total between $.75 \%$ to $1 \%$ of assets. Id. Additionally, tlie SEC Guide requires 
Despite this extensive regulatory apparatus, the fragility of the financial system has imcreased. The number of failures of federally imsured banks has risen drastically. ${ }^{53}$ The near failure and subsequent rescue of Continental Illinois National Bank has caused widespread concern over the safety of large banks. ${ }^{54}$ Recent failures in the Ohio ${ }^{55}$ and Maryland ${ }^{56}$ savings and loan industries have demonstrated that bank

disclosure of those foreign countries in which "current conditions ... give rise to liquidity problems which are expected to have a material impact on the timely payment of interest or principal on that country's private or public sector debt." Id. at 37,613. The potential that foreign borrowers will be unable to pay their debts with hard currency due to, for example, balance-of-trade deficits or currency restrictions is known as "transfer risk."

53. In 1985, 120 federally insured banks failed, the highest number since 1933. Home Savings Bank Fails, Bringing Total To 120 for the Year, Wall St. J., Jan. 2, 1986, at 28, col. 6 (w. ed.); see Nash, Adjusting to 100 Failed Banks, N.Y. Times, Nov. 16, 1985, at Bl, col. 3 (nat'l ed.). This contrasts sliarply with an average of four failures per year in the sixties, eight per year in the seventies, and ten failures in 1981. Id. at 23, col. 3; see Schares, Banks May Face Another Bad Year, San Francisco Chron., Feb. 4, 1985, at 52, col. 1. Presently, about 1100 of the 14,500 commercial banks are considered "problem banks," that is, banks having a signifieant chance of failure. Nash, supra, at B1, col. 3.

54. Rather than allowing the eighth largest U.S. bank to fail, federal regulators arranged for the government to guarantec all deposits of Continental Illinois in exchange for an $80 \%$ ownership interest in the bank. A Permanent Assistance Program for Continental Illinois National Bank and Trust Company, Issues IN BANK Reg., Spring 1984, at 6, 7 [hereinafter cited as Permanent Assistance Program]. The bailout was necessitated by uninsured depositors' witlidrawal of $\$ 10$ billion over a two-month period beginning in May 1984. Inquiry into Continental Illinois Corp. and Continental Illinois National Bank: Hearings Before the Subcomm. on Financial Institutions Supervision, Regulation and Insurance of the House Comm. on Banking, Finance and Urban Affairs, 98th Cong., 2d Sess. 275 (1984) (appendix to statement of C.T. Conover, Comptroller of the Currency) [hereinafter cited as Continental Illinois Hearings]. Depositors were concerned over mounting losses on energy loans the bank acquired from the failed Penn Square National Bank, itself formerly a large bank. See id. at 264-65 (loans purcliased from Penn Square were 3\% of Continental's total loans over the past two and one-half years, yet accounted for $41 \%$ of its loan losses, resulting by the fall of 1984 in almost $\$ 500$ million in loan losses).

55. Home State Savings Bank of Cincinnati collapsed in March 1985 after losing millions of dollars due to fraudulent conduct of E.S.M. Government Securities Inc., a Florida government securities repossession dealer. The loss was large enough to deplete the state-sanctioned, private insurance fund covering seventy other Ohio S\&L's. Depositors in other similarly insured institutions lined up to withdraw their inoney despite official pleas not to do so. In response, the governor of Ohio declared a banking holiday. Many of the S\&L's were allowed to open four days later, but on the condition that they obtain federal deposit insurance and limit withdrawals to $\$ 750$ per month until each is open for regnlar business. See Ansberry, Rose \& Winter, One Ohio S\&L Fully Resumes Its Operations, Wall St. J., Mar. 22, 1985, at 4, col. 1 (w. ed.); see also infra text aeeompanying notes 115-16.

56. The failure of Old Court Savings and Loan due to risky real estate and construction loans for all practical purposes depleted the private insurance fund, since its $\$ 150$ million in losses exceeded the size of the fund. The ensuing run against Old Court and the 101 similarly insured S\&L's in May 1985 resulted in the governor of Maryland imposing a bank lioliday and then allowing withdrawals of up to only $\$ 1000$ a month. The crisis with Maryland thrifts was worsened by the failure of Community Savings and Loan Association of Bethesda, which suffered as much as a $\$ 100$ million loss from its real estate leasing subsidiary, Equity Programs Investment Corporation (EPIC). The fragility in the Maryland institutions has remained for a long time, due to the length of time it took many of the affected institutions to qualify for federal insurance because of their financial condition. The remaining $\$ 1.2$ billion dollars in frozen deposits at the failed thrifts will probably not 
runs, not known since the Depression, are still an economic reahty.

Bank failure and depositor runs are inextricably linked to lending risks. In the past, insider lending and defalcation were often the primary cause of bank failures. ${ }^{57}$ A recent study by the federal government, however, concluded that during the 1970's and 1980's lending risks einerged as the priinary cause of bank failures. ${ }^{58}$ The slowdown of the energy, agriculture, construction and real estate industries and the consequent devaluation of the pledged collateral has caused many of the recent bank failures. ${ }^{59}$ Foreign lending also remains a potentially troublesome area of lending risks, both due to its magnitude ${ }^{60}$ and the risk of rescheduling or default. ${ }^{61}$ Part $I I$ argues that the current nondisclosure regime is unable

be fully disbursed to the affected depositors until 1989. See Swartz, Some Deposits in Maryland to Be Freed As State Seeks to Resolve Thrift Crisis, Wall St. J., Jan. 13, 1986, at 5, col. 1 (w. ed.); Nash, Thrift Quandary in Maryland, N.Y. Times, Nov. 25, 1985, at B1, col. 3 (nat'l ed.).

57. From January 1958 to April 1971, there were 59 bank failures. Professor Benston, using FDIC data, concluded that $66 \%$ of the failures were caused primarily by fraud or other irregularities, $26 \%$ by loan losses or brokered funds, and $7 \%$ due to mept management. Benston, Bank Examination, in STAFF of SENATE COMM. ON BANKING, Housing AND URBAN AfFaIRs, 94TH CONG., 1ST SESS., COMPENDIUM OF MAJOR IsSUES IN BANK REgulation 560-61 (Comm. Print 1975).

58. The FDIC analyzed the 124 bank failures from 1971 to 1982 and, disaggregating them into deciles based on asset size at the time of failure, found that losses on loans were the primary cause of bank failures in all size groups in a majority of the cases. This study found that $61 \%$ of the 124 bank failures were primarily caused by lending risks. FDIC, DePOSIT INSURANCE IN A CHANGING ENVIRONMENT II-18 to II-19 (1983).

59. Nash, supra note 53 , at 26 , col. 4 . The article notes that half of the 100 failures in the first eleven months of 1985 were banks with $25 \%$ or more of their loans in the agricultural sector. Private bank losses from agricultural lending are hikely to reach $\$ 10$ billion to $\$ 15$ billion. Charlier, Farm Fallout: Rural Crisis May Hurt Rest of the Economy, Many Experts Believe, Wall St. J., Dec. 24,1985 , at 1 , col. 6,6 , col. 1 (w. ed.). Souring energy loans also portend tronble for the banking systein. Of the 563 "energy banks," that is banks with energy-industry loans equal to $25 \%$ or more of their capital, 30\% are problem banks or near-problem banks. Nash, Woes Seen at 'Energy Banks,' N.Y. Times, Mar. 27, 1986, at D9, col. 1 (e. ed.).

60. The rapid incrcase in foreign lending has provoked much concern. In 1970 U.S. banks extended to foreign borrowers $\$ 50$ billion of credit, which grew to $\$ 400$ billion by 1981 . Reisner, Default by Foreign Sovereign Debtors: An Introductory Perspective, 1982 U. ILL. L. REV. 1, 2. In the decade following the 1973 oil crisis, loans by U.S. banks to non-OPEC developing countries increased 700\%. H.R. REP. No. 175, 98 th Cong., 1st Sess. 31, reprinted in 1983 U.S. CoDE CONG. \& AD. NEws 1898, 1914. The causes of this increase were: (1) the twin oil shocks of the 1970's and the need to recycle petrodollars, so that lesser developed countries could purchase oil, W. CLINE, INTERNATIONAL DebT: Systemic Risk AND Policy Response 8-11 (1984), (2) the tendency of banks to follow other banks into new markets without adequately considering risks, see supra note 6 , and (3) the "incapability evidenced over the past decade by the Federal banking agencies to effectively monitor and prevent the unsound operating and lending practices of U.S. banks." H.R. REP. No. 175, supra, at 30, reprinted in 1983 U.S. CODE CONG. \& AD. NEwS, at 1913.

61. The risk of loans to foreign countries has become more evident. The forced rescheduling of Mexican debt in August of 1982 was followed by the self-declared debt moratorium of Argentina in November of that year, the Brazilian decision in December to forego repayments of principal on its debt due in January 1983, and the requests by a number of other nations in the following summer to reschedule portions of their debt. Cohen, supra note 35, at 203 n.21; Terrel, Bank Lending to Developing Countries: Recent Developments and Some Considerations for the Future, 1984 FED. RESERVE BULL. 755, 755. In early 1984, Argentina again experienced problems paying its debt, and 
to prevent this inefficient risk taking by banks and has, in fact, encouraged it.

\author{
II
}

The Role of Confidence Production in Commercial BANKING

This Part explicates the function of confidence in commercial banking. Regulators have recognized the importance of confidence in the banking system:

One important consequence of the industry's problems has been a heightened public concern about the condition of U.S. banks. Market confidence is an unpredictable but crncial eleinent in the stability of individual banks and the banking system as a whole. Whether a bank survives adverse circumstances is often a matter of whether the market allows it the needed time to work out probleins. ${ }^{62}$

Confidence is a precondition of a functioning market-individuals are unwilling to participate in financial and real-asset markets without it. For example, absent the legal system's determination and enforceinent of property rights, individuals would not be willing to enter into contractual relations because of uncertainty that the obligations undertaken would be enforced. ${ }^{63}$

other nations had to contribute to prevent a possible default. Brief Reprieve: Argentine Debt Pact Avoids Trouble Now, May Cause Pain Later, Wall St. J., Apr. 2, 1984, at 1, col. 1 (w. ed.). The temporary halt in private debt repayments declared by South Africa in the summer of 1985, South Africa's Financial Markets Stable as Debt Moratorium Goes Into Effect, Wall St. J., Sept. 3, 1985, at 25, col. 2 (w. ed.), and the need to renegotiate the Mexican debt in the spring of 1986, Pine, U.S. Aides Work on Debt-Accord Details For Mexico, but Job Could Take Weeks, Wall St. J., June 12, 1986 , at $7, \mathrm{col} .1$ (w. ed.), reveals the contmuing vulnerability of U.S. banks from loans to the private and governmental sectors of foreign countries.

Some analysts consider foreign lending the real long-term threat to the stability of the U.S. banking system. See Bailey, Delaying the Day: Deferred Loan Losses At Thrifts and Banks Snowball Across U.S., Wall St. J., Jan. 8, 1986, at I, col. 6, 18, col. 3 (w. ed.) (estimating that loans to thirdworld countries may be worth at most 80 cents ou a dollar, and perhaps only 50 or 60 cents, and that "[w]riting off just $10 \%$ of this exposure would wipe out most of the combined annual profits of" the 10 largest bank holding companies).

62. Continental Illinois Hearings, supra note 54, at 199 (statement of C.T. Conover, Comptroller of the Currency).

The Supreme Court has relied on the need of banks to generate confidence to justify its holding that their participation in certain financial activities is barred by the Glass-Steagall Act, ch. 89,48 Stat. 162 (1933) (also known as the Banking Act of 1933) (codified as amended in seattered sections of 12, 15 \& 39 U.S.C.). Securities Iudus. Ass'n v. Board of Governors, 104 S. Ct. 2979, 2984 (1984) (placing commercial paper) (Losses from investment banking activities "eroded the confidence of depositors in the safety of banks as depository institutions. This crisis of confidence contributed to the runs on the banks that proved so devastating to the solvency of many commercial banks."); Investment Co. Inst. v. Camp, 401 U.S. 617, 631 (1971) (operating a mutual fund) ("[P]ublic confidence is essential to the solvency of a bank ....").

63. See M. Friedman, Capitalism and Freedom 27 (1962):

[T] he organization of economic activity through voluntary exchange presurnes that we have provided, through government, for the maintenance of law and order to prevent 
In financial markets, the enforcement of property rights alone cannot provide sufficient levels of confidence to ensure a stable market. Those markets utilize additional measures to produce confidence. For example, unlike the purchaser of a tangible product, such as an automobile, the imvestor in a financial market receives at most a paper memorial of the transaction. Consequently, should a dispute arise over the contractual relationship, there is often no tangible product to hold captive for self-help purposes. Furthermore, issuers of imvestment instruments and investors possess significantly different levels of information. This disparity creates immeasurable uncertainty about the quality of investments and encourages investors to demand additional confidence. ${ }^{64}$ In securities markets, issuers generated confidence through voluntary disclosure, even before enactment of mandatory disclosure requirements in the Securities Acts of 1933 and $1934 .{ }^{65}$

As for the banking system, since the Civil War period the federal government has played an active role in preserving depositor confidence. ${ }^{66}$ The National Bank Act of $1864^{67}$ had the effect of meeting consumers' needs for confidence by legislating limits on imprudent actions by banks, providing for national bank examinations, and creating national bank notes. The Federal Reserve Act of $1913,{ }^{68}$ wherem the Federal Reserve was established as the lender of last resort, was designed

coercion of one individual by another, the enforcemeut of contracts voluntarily entered into, the definition of the meaniug of property rights, the interpretation and enforcement of such rights, and the provision of a monetary framework.

Id.; R. Musgrave \& P. Musgrave, Public Finance in Theory and Practice 6 (1980) ("[T]he contractual arrangements and exchanges needed for market operation cannot exist without the protection and enforcement of a governmeutally provided legal structure.").

64. Cf. Arrow, Uncertainty and the Welfare Economics of Medical Care, 53 AM. ECON. REv. 941, 951 (1963) (buyer's greater uncertainty about quality of medical care, where both parties are aware of informational inequality, colors that economic relationship).

65. Easterbrook \& Fischel, Mandatory Disclosure and the Protection of Investors, 70 VA. L. REv. 669, 684 \& n.25 (1984). The level of voluntary disclosure, however, was inadequate for investors' needs. See J. Seligman, The SEC AND the Future of Finance 203 (1985) (noting "[t]he reluctance of many business corporations in the pre-1933 period to disclose what today is considered essential balance sheet and incoine statement data").

66. In fact, governments have regulated banks froin their earliest days in Renaissance Italy, $\mathrm{E}$. SYMONS, JR. \& J. WHITE, supra note 13, at 5, and government involvement in the American banking system preceded the Civil War period. The First and the Second Banks of the United States provided stability in a system of otherwise federally unregulated banks. Id. at 12, 14 . In midnineteenth-ceutury United States, even in the eighteen so-called free-banking states, state deposit insurance programs, requirements for holding certain bonds, and chartering requireinents partially instilled the confidence required by depositors. See K. CoOper \& D. Fraser, Banking Deregulation and the New CompettTion in Financial Services 46-47 (1984); Rolnick \& Weber, New Evidence on the Free Banking Era, 73 AM. ECON. REv. 1080, 1082-83 (1983).

67. Ch. 106, 13 Stat. 99 (codified as amended in scattered sections of 12, 19 \& 31 U.S.C.). See E. SYMons, JR. \& J. Whrte, supra note 13, at 24.

68. Ch. 6, 38 Stat. 251. The Panic of 1907 and the refusal of banks to honor requests to withdraw funds during that crisis preeipitated in part the passage of this Act. M. FRIEDMAN, supra note 63 , at 43 . 
to prop up banks facing temporary liquidity shortfalls and reduce fears of suspensions of convertibility. Finally, in 1933, after these nneasures had failed to generate sufficient public confidence in a time of a severe contraction, federal deposit insurance was established. ${ }^{69}$ As the economy has become more consumer oriented, the role of secrecy in the production of confidence has decreased, as evidenced, for example, by changes in bank disclosure policies. ${ }^{70}$

This Part discusses the ongoing role of confidence as an intangible good that depositors demand and banks must maintain at sufficient levels to prevent runs. Section $A$ provides models of depositor behavior in a banking market with asymmetrical flows of information. Section $B$ criticizes the attempts of the current nondisclosure regulatory regime to maimtain public confidence in the banking system.

\section{A. Models of Depositor Behavior, Confidence Production, and Bank Runs}

To determine the effectiveness of a regulatory regime, one must first understand the market that it will regulate. This Section first attributes depositor demand for confidence to asymmetrical flows of information. The second subsection then describes the production of confidence. The final subsection shows that an unregulated banking market is unable to produce the socially efficient level of confidence.

\section{Depositor Behavior in a Market with Asymmetrical Information Flows}

Under a system of fractional-reserve banking, a bank retains only a fraction of all deposits and invests the remainder in assets, often loans. A contract between the bank and depositor guaranteeing a return provides no information on the likelihood that the bank will have sufficient funds to make the specified payments. Although the bank can monitor the quahity of its investments, depositors do not necessarily have access to this information. Depositors, however, need this information to evaluate the adequacy of returns offered by the bank. ${ }^{71}$

69. See E. Kane, The Gathering Crisis in Federal Deposit Insurance 3 (1985).

70. See, e.g., Bankamerica Corporation, Voluntary Disclosure Code 3 (1978) (on file with author):

Traditionally, both bankers and bank regulators in the United States have tended to rely on secrecy and overt competitive restrictions which limit, rather than nurture, the development of competitive vitality. But the profound economic changes that have occurred since the present regulatory framework was established in the early 1930s, and the increased social expectations of the 1960s and 1970s, have produced changes, both in practices and attitudes, that dictate departure from traditions that are increasingly strained Id. and outdated.

71. K. COOPER \& D. Fraser, supra note 66, at 36-37. A well-informed investor would 
While depositors require information to make risk and return calculations, they will do so only if the expected gains from analyzing the data outweigh the costs of such analysis. The more money a depositor has at stake, the lower the cost per dollar deposited to monitor banks. Small depositors, therefore, reasonably may determine that it is more cost efficient to withdraw their funds at the first sign of trouble than to monitor the bank. ${ }^{72}$ A depositor using a withdrawal strategy, however, risks not being able to withdraw her funds before others also recognize the impendimg trouble and withdraw their funds. While small depositors might reasonably choose a withdrawal over a monitoring strategy, after a certain amount is deposited, the average depositor would then choose a monitoring strategy and demand information. ${ }^{73}$ Indeed, studies have shown that large institutional depositors are "very aware of currently disclosed data." 74

Information on loan quality, which is necessary to evaluate the safety of institutions, ${ }^{75}$ is often not available. The FDIC concluded in its 1983 report on deposit imsurance that "[e]ven for the analysis of risk im large banks, [financial advisers and sophisticated data users] would benefit from more data on loan quality." 76 The report noted that the data

demand higher returns for investing in banks that were riskier than the average bank. $C f$. $R$. BREALEY \& S. MYERS, supra note 4, at 140, 151 (applying this principle in the context of stockmarket investors).

72. K. COOPER \& D. FRASER, supra note 66 , at 40 . The authors also argue that this behavior is cheaper than depositing funds in many banks, id., presumably because such a course of action would necessitate watching for danger signals at each one.

73. Once reliable deposit insurance exists, fully insured depositors would no longer demand information.

74. FDIC, supra note 58, at IV-5. Based on the FDIC surveys, one commentator has concluded that:

Institutional investors, such as mutual funds and pension funds, are the most sophisticated in using financial data and exert the most market discipline. To qualify for investment, banks must meet size and performance requirements, which effectively limit investment to the 50 largest banks. Fund managers undertake extensive in-house analysis of banks, relying on newspapers, call reports, $10-\mathrm{K}$ and $10-\mathrm{Q}$ reports, and ratings services.

Gilbert, Disclosure and Market Discipline: Issues and Evidence, EcoN. REV., Nov. 1983, at 70, 71.

75. The importance of information for assessing lending risks follows from the fact that lending risks are the primary cause of bank failures. See supra note 58.

76. FDIC, supra note 58, at IV-2. The FDIC concluded on the basis of two surveys it conducted that "[s]ophisticated users would like to receive more data in specific areas. More and better data on loan quality, particularly on foreign loans, is considered very desirable." Id. at IV-10; see E. KANE, supra note 69, at 12 ("[T] ruly adequate information on the quality of assets and operating policies is hard to come by. Almost without exception and with regulatory connivance, financial statements published for deposit institutions are exercises in cosmetic accounting."); see also Berton, Legerdemain: Accounting at Thrifts Provokes Controversy as Gimmickry Mounts, Wall St. J., Mar. 21, 1985, at 1, col. 6 (midwest ed.) (noting that one-third of all S\&L's would not have a positive net worth if intangible assets like goodwill were cut from their balance sheets, and that approximately two-thirds of the industry's total profits in 1984 were generated by a controversial stock dividend from a quasi-governmental agency the S\&L industry owns and "questionable accounting in the finest tradition of Lewis Carroll" ") (quoting a New York thrift analyst).

A study of the pricing of common stock of five banks participating in Penn Square loans found 
available to depositors concerning small banks is even less complete. ${ }^{77}$

Regulatory restrictions are a major cause of this asymmetrical flow of information. As already discussed, ${ }^{78}$ the nondisclosure regime is premised on the need to keep information on banking risks secret to preserve depositor confidence. Regulations prevent banks from supplying already-assembled information demanded by large depositors. ${ }^{79}$

Because of this asymmetry, large depositors often must rely upon a withdrawal, rather than monitoring, strategy. ${ }^{80}$ This lack of information encourages uninsured depositors to withdraw their funds at the first sign of significant problems with their bank's loan portfoho. Even indications of trouble at another bank niay be grounds to withdraw. For exaniple, problems with another bank's loan portfoho may be the only information that depositors have about the quality of their bank's assets. ${ }^{81}$ Asymmetrical flows of information in a nondisclosure regime, therefore, increase the vuhuerability of the banking system to runs.

\section{A Model of Confidence Production}

Treating confidence as an intangible good ${ }^{82}$ that depositors demand and banks supply provides insights into both the decision of depositors to

that the market did not anticipate the substantial default risk in these loans until after the announcement of Penn Square's failure. The authors concluded that "[t]hese results would suggest that the current flow of information from large banks about the quality of their loan portfolios is not adequate for the market to make accurate assessments." Fraser \& Richards, The Assimilation of Market Information During a Bank Failure, in PROCEEDINGS of A CONFERENCE ON BANk STRUCTURE AND CoMpetition 531, 535 (1983) (Fed. Reserve Bank of Chicago). On the other hand, a different study showed that stock prices signaled difficulties at six banks an average of thirtythree weeks before regulators classified them as problem banks. Pettway \& Sinkey, Establishing OnSite Bank Examination Priorities: An Early-Warning System Using Accounting and Market Information, 35 J. FIN. 137, 145-46 (1980). But cf. Gilbert, supra note 74, at 73-74 (Money markets and capital markets "have been able to anticipate banking problems and react in an orderly manner. However, most of the evidence is based on a few bank failures in the mid-1970's. Updated analyses with a larger sample of bank failures would be useful to substantiate earlier findings." Id. at 74.).

77. FDIC, supra note 58, at IV-2.

78. See supra text accompanying notes 26-32.

79. Third-party effects-benefits bestowed on other users that the producer cannot charge for or cests that the produccr cannot be charged for-would prevent the removal of such regulation alone from resulting in an efficient level of disclosure. See infra text preceeding and accompanying notes 198-99.

80. See infra text accompanying notes $143-44$.

81. K. COOPER \& D. FRASER, supra note 66, at 40 . For example, banks in the Southwest have experienced a flight of funds because of depositor concerns over losses from energy loans. In response, some Texas banks have attempted to distingnish themselves from other energy lenders by stressing their smaller holdings of energy loans or their higher capital levels and loan-loss reserves. See Apcar, Energy Lenders Step Up Search For New Funds, Wall St. J., Apr. 24, 1986, at 2, cols. 1-2 (w. ed.).

82. An "intangible good" has no physical form, yet still is valuable to people. Examples of intangible goods include goodwill and trade secrets. See Ruckelshaus v, Monsanto Co, 104 S. Ct. 2862, 2873-74 (1984) (holding that trade secrets, although "intangible interests," can be "intangible property rights" and thus covered by the taking clause of the U.S. Constitution). 
run and methods of avoiding it. Confidence is a good because depositors consume it and its presence or absence influences their behavior. To properly formulate the regulatory decisions designed to prevent runs, it is essential to recognize that confidence affects depositor behavior im a manner distimct from the influences of risk and returu. The approach of this Comment is merely to disaggregate the components affecting depositors' decisions im order to construct a system of more effective regulation.

\section{a. Confidence Defined}

Individuals require confidence if they are to transact in a market. ${ }^{83}$ As previously argned, ${ }^{84}$ financial markets, including the banking system, require a greater level of confidence than nonfinancial markets. This requirement of confidence extends to particular firms within those markets. ${ }^{85}$ For the banking system, if depositors lack sufficient confidence in a particular bank, they will not undertake nor remain in creditor relationships with that bank.

For a financial market to exist, someone must agree to hold risk. ${ }^{86}$ Different people will demand different returns for holding the same amount of risk; ${ }^{87}$ the market return is that which equates supply and demand of funds. ${ }^{88}$ At times some people will refuse to hold a particular risk, because they view it as so immeasurable and so likely to cause a loss that they cannot determine a sufficient return for holding it. Such risk is labeled in this model "superrisk."

Superrisk is directly related to risk. First, like risk, superrisk can be

83. See supra text accompanying note 63 .

84. See supra text accompanying notes $64-65$.

85. To the extent that all banks are viewed as being equally sound, then confidence in the banking market and a specific bank are the same. See infra text accompanying notes 152-53.

86. Risk can vary in its degrec of measurability. Risk is a cost, since people would always prefer to make a certain sum of money rather than the same sum with some degree of risk of losing it. R. BREALEY \& S. MYERS, supra note 4, at 12, 129; see Hirshleifer \& Riley, The Analytics of Uncertainty and Information-An Expository Survey, 17 J. ECoN. LITERATURE 1375, 1379-84 (concluding that the average individual is risk averse). People can be induced to accept risk, however, in exchange for a return. See infra note 87. Of course, the inarket participants' risk can be shifted to third parties who can better bear the risk, such as private insurers or the FDIC. See generally L. Friedman, Microeconomic Policy ANalysis 206-17 (1984) (discussing riskpooling mechanisms and their implications for economic efficiency).

87. Deposits are loans to the bank; thus efficient returns should reflect default risk and market risk. See supra note 4. Differences in returns demanded may result from differences in (1) perceptions of expected outcomes, see Miller, Risk, Uncertainty and Divergence of Opinion, $32 \mathrm{~J}$. Fin. 1151 (1977), (2) cognitive abilities, and (3) risk aversion, see Baer \& Kolari, Risk Preferences and the Structure of Yield Spreads on Bonds, in ProceEdINGS of A CONFERENCE ON BANK STRUCTURE AND COMPETITION 92, 98-99 (1983) (Fed. Reserve Bank of Chicago).

88. L. FRIEDMAN, supra note 86, at 502, 511-15.

89. "Superrisk" is the condition where no return can compensate the particular depositor for holding the risk. This is distinguishable from the presence of a very large risk, which, for example, can be compensated for by a correspondingly large return or subdivided into sinaller parts by reinsuring it. 
described as a function of three variables: investors' cognitive abilities, risk aversion, and opinions on risk implications. ${ }^{90}$ Second, since all three variables can differ from person to person, it is likely that investors' determination that a course of action involves superrisk, as opposed to compensable risk, will differ. Third, as risk decreases, so does the incidence of superrisk because fewer investors will find the uncertainty as involvimg an imcalculable but nearly certain loss.

By definition, a person will not take a course of action involving superrisk. Confidence, which is the willimgness to transact with a firm or in a inarket, ${ }^{91}$ thus is defined in this model as the absence of superrisk. ${ }^{92}$ Just as people will possess different opimions concerning the existence of superrisk, so too will they possess different perceptions of confidence.

Applying these concepts in the banking context, superrisk arises where a depositor cannot fully calculate the risk of bank failure but views it as nearly certain. Because no return can compensate a depositor for leaving his funds in a bank that involves superrisk, he will withdraw them. When withdrawals by a significant number of depositors reach some critical mass, a run on the bank will result. ${ }^{93}$ Runs may spread to

90. See supra note 87. Cf. generally F. KNIGHT, Risk, UNCERTAINTY AND Profit 241-42 (1921) (listing factors that cause people to handle differently "uncertainty," which he defined as risk "not susceptible to measurement and hence to elimination," id. at 232, 233-34). Frank Knight's distinction between risk and uncertamty and his argument that economic profits derive from holding uncertainty, $i d$. at $215-16,232$, differ from the risk/superrisk distinction developed here, because an investor will not hold superrisk no matter what the promised return. From the perspective of depositors withdrawing because of superrisk, depositors remaining with the bank might seem to be holding superrisk; however, they are from their own perspective only aecepting compensable risk.

91. See supra text accompanying note 63 .

92. Hyman Minsky constructed a model of "confidence," in which he defined it as mere uncertainty of estimates of future yields on assets. Minsky, Financial Instability Revisited: The Economics of Disaster, in REAPPRAISAI OF THE FEDERAL RESERVE DISCOUNT MECHANISM 107-08 (1972), reprinted in First Meeting on the Condition of the Banking System: Hearings Before the Senate Comm. on Banking, Housing and Urban Affairs, 95th Cong., 1st Sess. 398.99 (1977). "Confidence" in that model simply entails differing degrees of certainty and corresponds to mere risk in the terminology of this Comment.

93. "The term critical mass is defined in physics generally as the mass of fissionable material required to produce a self-sustaining sequence of fission reactions in a system, or the minimum mass of fissionable material that will sustain a chain rcaction." L. JONES, UNIVERSITY BUDGETING FOR CRITICAL MASS AND COMPETITION 40 (1985) (emphasis in original) (applying critical mass model to academic planning in order to determine the minimum program breadth required to sustain viable disciplinary studies); see Diamond and Dybvig, supra note 9, at 410-11 (presenting a model of bank runs that is consistent with a critical-mass process, because guaranteed suspension of convertibility at a critical point causes other depositors not to run).

An alternative view of bank runs is that their momentum reflects the period of dissemination of bad news throughout the depositor base, rather than a sudden unraveling onee a critieal number of depositors decide to withdraw. The news that other depositors are withdrawing en masse, with its implications for bank liquidity, is one of the worst pieces of information in a fractional-reserve banking system because it may indicate to depositors that a critical mass may have already occurred. See Black, Miller \& Posner, An Approach to the Regulation of Bank Holding Companies, 51 J. Bus. 379,390 (1978). The critical-mass aspects of a bank run seem to exist even in an informationdissemination model. 
other banks where depositors view the risks associated with their banks as similar to those of the failed bank..$^{94}$ Such similarity may presage the failure of their banks, and thus encourage depositors to reassess the risk as involving superrisk..$^{95}$

The production of confidence, as that term is used here, is merely the elimination of superrisk for some number of depositors. Once superrisk is eliminated, ${ }^{96}$ a rational depositor will hold any degree of risk for appropriate returns. Banks will produce at least enough confidence to eliminate the superrisk of a sufficient number of depositors to mamtain a stable deposit base. Under this model, a bank's confidence production decision turns on the confidence demands of the critical depositor. The critical depositor is the "nth" person whose decision to withdraw funds would trigger a critical-mass process leading to a run on the bank. There must be enough confidence to satisfy that critical depositor for the bank to avoid a run.

This model of confidence production is consistent with the fact that many uninsured depositors are institutional imvestors. Institutional investors inay experience superrisk less frequently than small depositors because they have more resources available for analyzing risk. ${ }^{97}$ Superrisk, though, is still a very real possibility. Institutional investors are unable to determine fully bank soundness because of asymmetries in information. ${ }^{98}$ Furthermore, not all large investors carefully analyze bank condition. Many beheve that the government will not allow a large bank to fail ${ }^{99}$ and probably intend to withdraw at the first sign of trouble. Soine institutional investors are more risk averse because of their fiduciary duties and the threat of legal hability. ${ }^{100}$ Finally, the existence of superrisk for an institutional investor is dependent on the characteristics of the money manager. Specialization may cause many money managers to perceive and react to risk similarly, ${ }^{101}$ but their investment behavior, including their willingness to hold risk, can vary depending on their per-

94. See supra note 81 and accompanying text.

95. See infra note 123 .

96. Since confidence is a precondition for transacting with a bank, individual depositors' demands are insensitive to price. Absent changes in superrisk assessments, depositors will neither pay for more confidence nor settle for less.

97. See supra note 74. Firms also can use outside analysts. See Unger, Using Outside Research, J. PORTFOLIO MGMT., Spring 1983, at 43 (discussing experience of $\$ 690$ million fund, which relies on outside research).

98. See supra text aecompanying notes 75-77.

99. See Gilbert, supra note 74, at 71 (describing behavior of corporate treasurers); $c f$. Murphy, Regulating Public Employee Retirement Systems for Portfolio Efficiency, 67 MINN. L. REV. 211, 22937 (1982) (discussing factors causing inefficient portfolio management based on ease studies of Ohio and Minnesota public-employee pension funds).

100. See Siegel, The Impact of Pension Reform on Portfolio Management, J. Portfolio Mgmt., Winter 1975, at 21, 23.

101. See F. KNIGHT, supra note 90 , at $244-45,269-70$. 
sonalities. ${ }^{102}$ The observed flight of institutional investors from failing and problem banks suggests that they are "not only interest sensitive, but extremely confidence sensitive." 103

\section{b. Forms of Confidence: $\mathrm{N}$-Confidence and $\mathrm{X}$-Confidence}

A regulatory system charged with preserving systemic stability shonld focus on confidence production. The inputs in the confidenceproduction process can be broadly grouped as "intrinsic confidence" ( $N$ confidence) and "extrinsic confidence" (X-confidence). N-confidence is produced by an individual firm in the banking sector, while X-confidence must be produced from without, either by an mdustry association or the government. Examples of N-confidence include information, goodwill, capital reserves, hquidity reserves, and private exammations. ${ }^{104}$ Examples of X-confidence include de jure federal deposit insurance, ${ }^{105}$ de facto

102. See, e.g., Farrelly \& Reichenstein, Risk Perceptions of Institutional Investors, J. PORTFOLIo MGMT., Summer 1984, at S, 6 (reviewing studies of investor behavior and concluding that " $[t]$ he amount of risk perceived and investment behavior vary from individual to individual and can depend upon such conditions as how much the particular investor feels that lie controls his environment, the prior existence of a specific stock in the investor's portfolio at time of purchase, and the relationship of expected return to the investor's determined target"); LeBaron, $A$ Psychological Profile of the Portfolio Manager, J. PoRTFolio MGMT., Fall 1974, at 13, 14-15 (discussing changing pressures on portfohio managers and noting that one survey concluded that they "were demoralized, unable to be rational").

103. Homan, Their Effect on the Liquidity and Solvency of American Banks, in STAFF of Senate Comm. on Banking, Housing and Urban AfFairs, 94th Cong., 15T Sess., Compendium of Major issues on Bank Regulation, 245, 267 (Comm. Print 1975). The author based his conclusions on his analysis of the crises faced by United States National Bank of San Diego in 1973, Franklim National Bank of New York in 1974, and Security National Bank of Long Island in 1975.

The recent experience of southwestern banks trying to maintain deposit bases and attract new funds, despite the widely publicized decline in the quality of oil loans, shows the importance of confidence in banking. Some banks have tried to increase depositor confidence by diselosing concentrations of energy loans or capital levels to large investors. Apcar, supra note 81, at 2, cols. 12. The risk/superrisk distinction is illustrated by the fact that some money managers will accept the increased risk of failure in exchange for higher returns, id. (many banks are offering premiums to attract large depositors), while others refuse to place funds with those banks, id. (discussing the withdrawal of institutional depositors from southwestern banks and coneluding that "[i]nstitutional investors in New York and other money centers are more likely to avoid the risk and take their cue from services that rate banks").

104. For example, banks can produce confidence by allcviating the asymmetrical information flows by disclosure, thereby facilitating depositor risk-and-return calculations. Liquidity is also an important generator of confidence, because it represents the bank's ability to satisfy withdrawal demands without liquidating assets. For a discussion of the role of capital reserves, see infra text accompanying notes $159-168$.

105. De jure federal deposit insurance guarantees the first $\$ 100,000$ of a depositor's account. 12 U.S.C. $\S \S 1811,1813(\mathrm{~m})(1)(1982)$. There is no superrisk for deposits below this sum, assuming that Congress would cover any shortfall in the fund. K. COOPER \& D. FRASER, supra note 66, at 161-62. In March of 1982, Congress passed a nonbinding resolution pledging to guarantee the liabilities of the funds. H.R. Con. Res. 290,96 Stat. 2639 (1982). 
deposit insurance, ${ }^{106}$ lender-of-last-resort provisions, ${ }^{107}$ banking regulations, and bank examinations. ${ }^{108}$

The government seems to be able to produce X-confidence more efficiently than the private sector could by use of an industry association, for example. As an illustration, the federal government is best able to provide deposit insurance for banks. Because bank failures are often cyclical, private insurers and state-sponsored funds are unable to adequately remsure against the risk of a large number of bank failures because assets in the insurers' portfolios would also be declining in value. ${ }^{109}$ Given its capacity for deficit spending, the depth of its resources, aud the ability to diversify risk nationwide, the federal government is the logical insurer of deposits or guarantor of nonfederal insurers. ${ }^{110}$ Other types of X-confidence, such as the lender-of-last-resort function and de facto deposit insurance, similarly enjoy the prestige and national uniformity that cannot be inatched by rules and examinations of private associations ${ }^{111}$ or the states. ${ }^{112}$

106. For example, FDIC-arranged mergers, wherein the purchasing institution assumes the liabilities of a troubled bank, prevent losses to uninsured depositors. This de facto deposit insurance exists because allowing a bank to fail entails costs of paying out deposits and the potential for community disruptions and reductions in public confidence. See E. Kane, Putting Teeth into FDIC Coverage Limitations Will not Solve the Deposit-Insurance Problem 2 (March 1983) (paper submitted to the FDIC) (on file with author).

107. As a lender of last resort, the Federal Reserve can make funds available to banks in liquidity binds so that they are not forced to liquidate their assets at a loss. The Federal Reserve's use of lender-of-last-resort powers has served in the past as a form of de facto deposit insurance. Before the FDIC-arranged inerger of Franklin National Bank in 1974, such lending afforded large depositors time to remove funds, so that large depositors were not at risk. Kareken \& Wallace, Deposit Insurance and Bank Regulation: A Partial-Equilibrium Exposition, 51 J. Bus. 413, 432 \& n.18 (1978). The same phenomenon took place in the recent crisis at Continental Illinois National Bank, where from May through July 1984 the bank borrowed $\$ 3.55$ billion from the Federal Reserve Bank of Chicago, \$4 billion from the FDIC and seven major U.S. banks, and over \$4 billion from a consortium of 28 banks, while Continental's deposits, federal funds and repurchase agreements fell by nearly $\$ 10$ billion. Continental Illinois Hearings, supra note 54, at 274-76 (appendix to statement of C.T. Conover, Comptroller of the Currency).

108. The first three examples of $\mathrm{X}$-confidence eliminate superrisk by limiting potential losses. The last two examples produce confidence by limiting bank activities and reducing the possible causes of loss, thereby facilitating the calculation of risks involved and decreasing the incidence of superrisk.

109. Mayer, Preventing the Failures of Large Banks, in STAFF OF SENATE CoMm. ON BANK1NG, Housing AND URBAN AfFaIRS, 94TH CONG., 1ST SESS., COMPENDIUM OF MAJOR ISSUES IN BANK Regulation 862 (Comin. Print 1975). Compared to federal insurance programs, state programs are less stable because of the limited geographical area covered and the smaller membership base. FDIC, supra note 58, at G-15.

110. K. COOPER \& D. Fraser, supra note 66, at 51.

111. The ability of private associations to set and enforce standards is at the sufferance of its members. Thus, it is unlikely that unpopular standards will be established. J. SELIGMaN, supra note 65, 238-40. The recent inability of the New York Stock Exchange to enforce nonvoting common stock prohibitions is a ease in point. Klott, A Fight Over Unequal Stock, N.Y. Times, Oct. 22, 1985, at 29 , col. 3 (nat'l ed.).

112. Federal requirements avoid the incentive of states to match less stringent laws of other 
While the banking system relies on both $\mathrm{N}$-confidence and X-confidence, they are to some extent substitutable. For example, increases in deposit insurance may allow reductions in bank capital levels. ${ }^{113}$ Some minimum amount of $\mathrm{X}$-confidence, however, is needed to counter the market fragility engendered by those depositors who find it cost effective to follow a witlidrawal strategy. ${ }^{114}$ As long as small depositors use a withdrawal rather than a monitoring strategy, $\mathrm{N}$-confidence alone cannot prevent such runs.

The recent run in Ohio illustrates the inability of $\mathrm{N}$-confidence to coinpletely substitute for X-confidence. The depletion of the state-sanctioned private insurance fund from losses at just one thrift institution effectively eliminated the largest source of X-confidence for the state's privately insured savings and loans system. ${ }^{115}$ Small depositors indiscriminately ran against the previously insured institutions and depleted the reserves of some of the financially strongest firms. ${ }^{116}$

Some amount of $\mathrm{N}$-confidence will also be required for the efficient production of confidence. Because uninsured depositors cannot be certain whether their funds will be fully covered by de facto insurance, they will continue to demand $\mathrm{N}$-confidence. Even if $100 \%$ de jure deposit insurance were enacted, ${ }^{117}$ depositor confidence in the banking system

jurisdictions in order not to competitively disadvantage banks in their jurisdiction. See J. SELigman, supra note 65, at 238.

113. Peltzman, Capital Investment in Commercial Banking and its Relationship to Portfolio Regulation, 78 J. PoL. ECON. 1, 4 (1970).

114. For example, deposit insurance should be set at a point where a monitoring strategy becomes cost efficient. See supra text accompanying note 72 . The current $\$ 100,000$ limit covers about three-quarters of all deposit dollars, although this figure varies by bank. Schares, How to Pick a Safe Bank, San Francisco Chron., Feb. 6, 1985, at 25, col. 2 (noting that almost fifty percent of the deposits in the failed Penn Square Bank were uninsured). Thirteen other countries currently have some form of deposit insurance, with almost all having been instituted following a banking crisis. McCarthy, Deposit Insurance: A Comparative Survey, in Proceedings of A CoNference ON BANK Structure AND COMPETITION 219, 219-20 (1980) (Fed. Reserve Bank of Chicago).

115. Thrift Crisis: Closing of Ohio S\&Ls After Run on Deposits Is One for the Books, Wall St. J., Mar. 18, 1985, at 1, col. 6, 6, cols. 3-4 (e. ed.).

116. Id. at 1, col. 6, 6, cols. 2-4. After declaring a holiday and closing all 70 thrifts, the governor's office planned to implement a "campaign of confidence" to convince the depositors that the thrifts were safe. Hertzberg, Rose, \& Solomon, Some Thrifts in Ohio to Start Opening Soon, Wall St. J., Mar. 21, 1985, at 2, col. 2; see supra note 55.

The same phenomenon of a run which followed upon the potential depletion of the private deposit insurance fund by a thrift's failure occurred two months later in Maryland, see supra note 56, and in 1976 in Mississippi, see Leff \& Park, The Mississippi Deposit Insurance Crisis, BANkERS MAG., Summer 1977, at 74, 74, 76-79.

117. For articles proposing a $100 \%$ deposit-insurance scheme, see Mayer, supra note 109, at 860-61; Tussing, Bank Failures and the Public Interest, in STAFF of SENate Comm. on Banking,

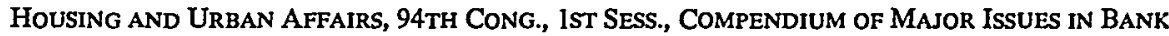
Regulation 833, 842-43 (Comm. Print 1975); Black, Miller \& Posner, supra note 93, at 391-92, 406-07. These articles argue for risk-priced premiums as a supplement to the $100 \%$ insurance proposal, so that banks would internalize the full cost of providing for this $\mathrm{X}$-confidence. If regulators cannot measure risk precisely enough, then insulating banks from market discipline will 
would not be guaranteed. Depositors would become indifferent to the quality of bank assets and would likely channel their funds to those banks offering the highest returns. Such pressure for high returns could encourage banks to engage in increasingly risky lendmg activities. ${ }^{118}$ Should a number of banks engaging in risky lending collapse, the insurance fnnd could well be depleted. This might cause depositors to question the government's ability to make good on the $100 \%$ guarantee and lead to a banking panic, ${ }^{119}$ as occurred in Ohio.

Thus, banks can satisfy depositors' demands for confidence with either $\mathrm{N}$-confidence or X-confidence. While a certain amount of substitution between these two types of confidence is possible, a stable banking system requires some minimum amount of each type. The next subsection discusses the failure of the market to induce sufficient production of confidence which increases the market's proclivity for bank runs and creates the need for government intervention.

\section{Market Failure in Confidence Production}

Banks must provide enough confidence to satisfy the demands of the critical depositor. To the extent that $\mathrm{X}$-confidence apphes to a particular bank, that bank can produce less $\mathrm{N}$-confidence. By observing depositors' willingness to rely on $\mathrm{X}$-confidence, a bank can determine if it needs to produce more $\mathrm{N}$-confidence to stabilize its deposit base. ${ }^{120}$ Banks will produce confidence up to the point where their net benefits from confidence production are maximized. This will be a function of the bank management's risk aversion, the probabilities it assigns to possible outcoines of asset decisions, and the present value of the associated expected payouts. Although a certain amount of risk of bank failures is probably economically efficient, ${ }^{121}$ market incentives cause an unregnlated bank-

increase risk taking and threaten the safety of the system. It is for this reason that the FDIC favors reductions in de facto deposit insurance. FDIC, supra note 58, at III-3.

118. K. COOPER \& D. FraSER, supra note 66, at 169-70. Since the amount of funds covered by insurance would be within the depositors' control, a moral hazard would develop. Depositors would give funds to those institutions offering the highest returns, regardless of their safety. The existence of a moral hazard prevents the conclusion that optimal risk bearing necessarily will result from $100 \%$ insurance. See Feldstein, The Welfare Loss of Excess Health Insurance, 81 J. PoL. Econ. 251, 252 (1973). An extensive regulatory regime would be needed to counter this tendency, and might include interest ceilings (along with their tendency to cause disintermediation in times of volatile price levels), high eapital standards, more frequent examination of the banks' liability position, and a willingness to quickly close seriously troubled banks. Otherwise, those banks on the brink of insolvency would be setting the price for deposits.

119. Black, Miller, \& Posner, supra note 93, at 392.

120. Banks need not explicitly consider the amount of X-confidence and $\mathrm{N}$-confidence; more realistically, banks observe depositors' withdrawal activities and take actions, such as increasing liquidity reserves, when withdrawals differ significantly from normal levels.

121. Preventing the worst managed firms from failing would be very costly and keeping such firms in the banking system would create instability. See generally BLUEPRINT, supra note 15, at 35 
ing systein to produce too little confidence, which renders it overly susceptible to bank runs.

Individual banks liave an incentive to undersupply confidence. Because of asymmetrical information flows, individual banks may benefit froin confidence produced by otler banks and thereby may reduce the amounts of $\mathrm{N}$-confidence they produce. Without knowledge of the quality of a bank's loan portfoho, uninsured depositors estinate the superrisk of dealing with a bank based on their impression of the average bank and demand a level of confidence consistent with that estimate. Further1nore, deposit insurance encourages depositors to view all banks as equally safe. Banks therefore have an incentive to "free ride" on the confidence produced by other banks and the government.

Banks also tend to underestimate the costs of failing. Although a bank failure imposes externalities upon other economic actors, the manageinent, owners, and depositors of the faihing bank do not have to bear those costs. For exainple, hquidation of long-term bonds in a thin inarket will reduce the value of similar bond portfolios of sound banks. ${ }^{122}$ These externalities cause the individually efficient level of confidence to diverge from the socially efficient level. Second, given asymmetrical information flows, the failure of a bank previously thought to entail average risk lowers tle confidence of depositors in all banks, which increases banks' confidence-production costs. ${ }^{123}$ Botl1 of these factors can cause an individual bank failure to lead to a generalized banking panic. ${ }^{124}$ For

(noting that the goal of financial stability is not equivalent to a policy of never allowing financial firms to fail, which "could ouly be achieved through public subsidies").

122. In other words, the less an asset is generally traded, the greater the percentage of supply that the hquidation will represent. The atteinpt to sell might result in a glut of the asset on the inarket, forcing the seller to take a loss. The decline in the value of assets can cause the failure of solvent banks when their assets no longer exceed liabilities. See M. FriEDMan \& A. SchWARTZ, supra note 3 , at $355-56 \&$ n. 65 .

With respect to the banking crises of 1930,1931 and 1933, these authors concluded that "[t]he impairment in the inarket value of assets held by banks, particularly in their bond portfolios, was the most important source of impairment of capital leading to bank suspensions, rather than the default of specific loans or of specific bond issues." Id. at 355 (footnote ounitted). For example, the percentage decreases in bond market values from mid-1931 to mid-1932 was significant: foreign bonds, $45 \%$; railroad bonds, $36 \%$; public utility bonds, $27 \%$; industrial bonds, $22 \%$; and U.S. government securities, $10 \%$. Id. at 355 n. 65 .

123. The loss of confidence due to the exposure of near-insolvent banks can also lead to a bank run. See Wright, $A$ Projected Resilient Financial Environment, in Financial CRISEs 173, 178 (E. Altman \& A. Sametz eds. 1977) (discussing reductions in confidence due to the failure of Franklin National Bank); see also supra note 81 and aecompanying text.

124. K. COOPER \& D. FRASER, supra note 66, at 40-41 (calling it the "domino effect"). For an exainple of this contagion effect, see the discussion of the panic that followed the failure of the Bank of United States during the Depression in M. FR1EDMAN \& A. SCHWARTZ, supra note 3, at 355.

More recently, the FDIC received fifteen requests for applications from privately insured thrifts in Massachusetts after the closing of the Ohio savings and loans, compared with one request in the past two years. Baum, Some Massachusetts Thrifts Inquiring About Federal Insurance for Deposits, Wall St. J., Mar. 22, 1985, at 4, col. 2 (w. ed.). Massachusetts has now ordered its thrifts to obtain 
example, a number of bank failures can cause a contraction $m$ the money supply ${ }^{125}$ and discourage banks from carryimg out their role in credit intermediation, ${ }^{126}$ either of which can cause a recession. In an unregulated market, however, banks do not have any incentive to produce the extra confidence valued by third parties because there is no easy mechanism for banks to charge them for the benefits received. Government regulation, therefore, is needed to ensure the production of a socially efficient level of confidence.

\section{B. The Importance of Information for a Stable Banking System}

The previous Section depicted how the banking system devolves to instability, unless a third party, such as the government, intervenes. This Section links the current nondisclosure regime for regulating banks with the mcreasing fragility of the banking system and shows the futility of regulatory changes within the framework of the nondisclosure regime. This Section demonstrates the importance of $\mathrm{N}$-confidence, and specifically information, in maintaining depositor confidence and a stable banking system.

\section{The Inadequacy of a Nondisclosure Regime}

The nondisclosure regime of banking regulation rehies on government supervision and owner hability to the exclusion of supervision by informed depositors. Owner hability in the form of increased capital requirements for banks supposes that shareholders can affect the risk taking of banks. This in turn assumes shareholder knowledge and control. Government supervision combined with restrictions on the availability of information necessary for private supervision must rest on the premise that the government alone can best control bank risk taking, making pri-

FDIC coverage due to the Ohio and Maryland panics. FDIC Expected to Insure 94 Massachusetts Thrifts, Wall St. J., Dec. 10, 1985, at 18, col. 1 (w. ed.).

125. The money supply will contract as banks increase their supply of hiquid assets and recall loans, thus reducing inoney available for investment. For exaniple, during the period from August 1929 to March 1933, the money supply declined by 35\%, which reflected mainly the fall in the ratio of deposits to cnrrency. M. FRIEDMAN \& A. SchwarTz, supra note 3, at 332-33; see M. FrIEDMAN, supra note 63, at 50 (linking severe declines in the money supply with recessions). See generally F. ZAHN, MACROECONOMIC THEORY AND POLICY 288-90 (1975) (discussing relationship of currency ratio to the money supply).

126. A recent study enphasized the importance of bank credit intermediation to aggregate deinand. Bernanke, Nonmonetary Effects of the Financial Crisis in the Propagation of the Great Depression, 73 AM. ECON. REV. 257 (1983). The writer argued that banks, as specialists in differentiating between good and bad credit risks, could charge low rates for credit intermediation. The failure of a number of banks, however, led to a fear of widescale bank failure and runs by depositors against sound banks. Furthermore, bankers mcreased liquidity to guard against runs, reducing their credit intermediation. Although new financial actors began providing credit intermediation, they were not as efficient as banks and had to charge more for that service. The result was a severe contraction of credit. 
vate participation through informed econonic actors unnecessary or even destabilizing. This subsection exposes the shortcomings of the supervisory capabilities of a nondisclosure regime. Part III then questions the harms of disclosure.

The starting point for a critique of the nondisclosure regime is the dynamic risk of the emerging financial-services market. The character of risks facing bank depositors is undergoing significant changes, which should cause depositors to demand increased levels of confidence. The FDIC concluded in its recent study of deposit insurance:

Bank leverage, particularly at large institutions, has been increasing for years. Interest ceilings on deposits are being dismantled. Banking organizations are expanding into new activities, in response to inroads by nonbank competitors, and into new locations. These forces have all contributed to a inore risk-intensive, less-constrained environment which is likely to be less forgiving of faulty financial and credit judgments. ${ }^{127}$

Banks facing more competition from new financial-services institutions will have to look harder for quality assets, and in the process may make loans with more potential risks. ${ }^{128}$

Banks also face increased risks on the liability side of their balance sheets. The deregulation of interest rates paid for deposits has eliminated an inexpensive, fixed-price source of funds available to banks. ${ }^{129}$ The entry of nonbank financial institutions into banking-type activities has increased the competition for depositors' dollars. ${ }^{130}$ Ironically, sinultaneous with funding costs becoming more unpredictable, banks have increased their reliance upon hability management, with its einphasis upon volatile, short-term funds. This strategy necessitates that banks become more adept at forecasting hquidity demands and avoiding mis-

127. FDIC, supra note 58, at III-3.

128. See id. at II-3 ("[E]conomic realities and competitive pressures, and the deregulation they demand, mean banks will be under greater pressure to take risks.").

129. The Depository Institutions Deregulation Act of 1980 requires the phasing out of interestrate ceilings for deposits. 12 U.S.C. $\$ 3503$ (1982).

Given the large spread between the fixed rate of interest paid on deposits and the return on the banks' investments, this deregulation may siguificantly cut into banks' profits. Pollock, The Future of Banking: A National Market and its Implications, in Proceedings of A CoNference on BANK STRUCTURE AND COMPETITION 31, 34 (1982) (Fed. Reserve Bank of Chicago) (estimating that in 1980 about $50 \%$ of profits of 31 of the largest 50 U.S. banks were due to payment of below-market interest rates on deposits). The deregulation of interest rates, however, was needed to allow banks to compete for funds with emerging alternative nonbanking investments. Congress recognized that interest ceilings provided for under regulation $Q$ "impede the ability of depository institutions to compete for funds." 12 U.S.C. § 3501(a)(1) (1982).

130. See Brownstein, Financial Services Companies Hope Consumers Will Buy One-Stop Shopping, 16 NAT'L J. 504 (1984) (discussing efforts of securities firms to form financial services conglomerates); Pavel, Rosenbloom, \& Siegel, Banks and nonbanks: $A$ run for the money, EcoN. PERSP., May-June 1984, at 3 (quantifying entry of nonbank financial institutions into traditional banking areas). 
takes that could cause the flight of these funds. ${ }^{131}$ Until the market has adjusted to these changes, depositors will be unable to ascertain and gauge the determinants of safety. Consequently, depositors will be less willing to invest without increased confidence.

These increasing risks and the reduced profit margins available for absorbing losses have made banking a field less tolerant of managerial incoinpetence. The banking regulatory regime therefore should facilitate the elimination of inefficient management and assure adequate confidence levels. The nondisclosure regime fails in these tasks in four ways: (1) it encourages the underproduction of confidence and overreliance on $\mathrm{X}$ confidence; (2) perversely, it shifts the increased risks of banking to the governinent by providing incentives for banks to inefficiently increase risk taking; (3) it insulates incompetent management and misdirects the flow of depositors' funds; and (4) it increases the susceptibility of the banking system to runs and the economy to speculative financing.

First, the nondisclosure regime makes it likely that depositor demands for increased confidence resulting from increasing risks will be satisfied by increased rehance upon de jure and de facto federal deposit insurance, rather than $\mathrm{N}$-confidence. As long as depositors perceive that the federal government is able and willing to cover deposit losses, a nominally fixed level of insurance will cover any amount of risk. Because deposit insurance is not risk priced, ${ }^{132}$ banks prefer this mechamsin to produce extra confidence. Simply stated, it costs banks nothing to generate increased confidence by relying upon de jure and de facto federal deposit insurance. ${ }^{133}$ The tendency of depositors to underdemand confidence along with the limited substitutability of X-confidence for $\mathrm{N}$-confidence cause depositors to accept a larger than efficient quantity of $\mathrm{X}$ confidence to offset the increased incidence of superrisk.

Second, taxpayers, not bank owners or depositors directly, pay the cost of this reliance upon X-confidence to cover increasing risks. ${ }^{134}$ The social cost of de jure and de facto federal deposit insurance is the probability of various losses multiplied by their maguitude. Social cost can be represented by an actuarial premiun charged for each insured

131. See Homan, supra note 103, at 267-68.

132. For a discussion of the pricing of deposit insurance, see E. KANE, supra note 69, at 66-72.

133. The costs of deposit insurance include the implicit premium of compliance with regulations imposed by the FDIC. Buser, Chen \& Kane, Implicit and Explicit Prices of Deposit Insurance and the Bank Capital Decision, in Proceedings of a Conference on Bank Structure and COMPETITION 174 (1980) (Fed. Reserve Bank of Chicago). Increases in these implicit premiums probably lag behind increases in risk, E. Kane, supra note 106 , at 8 , thus the costs to the bank to generate increased confidence is zero until the realignment of regulatory practices. This window for subsidized speculation is probably due to the FDIC's desire to make deposit insurance attractive to banks, Buser, Chen \& Kane, supra, at 180, and the bureaucratically inevitable lag between increasing risks and regulatory responses, E. KANE, supra note 69, at 19.

134. E. Kane, supra note 106 , at 4. 
dollar. The cost to the taxpayers is the difference between this actuarial premium and the lower premium actually charged banks. ${ }^{135}$

Taxpayers subsidize bank acquisitions of risky assets by bearing banking risks through depository insurance. Such subsidies thereby sever the pursuit of risks from its costs and make risky portfolio decisions more likely. ${ }^{136}$ Banks will price the activities that resulted in the demand for a higher level of confidence at less than their social cost and will be more willing to undertake them. Assuming that banks pass through the premium earned for making risky loans, depositors will be unable to distinguish between those banks that offer high interest rates due to wellperforming portfolios versus improbably successful, inefficiently risky portfolios. Depositors lack the information needed to avoid placing funds with banks engaging in risky behavior. The stability of the banking system will be reduced, while the potential hability of the government will increase.

A third problem caused by the overreliance on X-confidence is the distortion of uninsured depositors' choice of banks. Because larger banks will benefit most froin X-confidence for increased risk, ${ }^{137}$ depositors will likely shift their funds to those institutions. For exainple, studies of the market for certificates of deposit (CD's) show that uninsured depositors

135. See id. One reason that deposit insurance is not actuarially priced is that the premiums do not reflect the benefits of de facto insurance. Cf. id. at 3 (arguing that bank risk taking is inefficient because the "unpriced blanket guarantees for large institutions" subsidize it).

136. FDIC, supra note 58, at II-4 ("The combination of deregulation, little market discipline, and a flat-rate insurance premium, may well cause the incidence of excessive risk-taking to reach an intolerable limit."); see E. KANE, supra note 69, at 17-20. This is especially true where banks benefit from de facto insurance, as "banks in the nation's largest size class fac[e] strong incentives to develop a subsidized exposure to unregulated risks." Id. at 20; see supra note 118 (discussing moral hazards under deposit insurance). This incentive to inefficiently increase risk taking occurs even where the premise of shareholder control is most likely to be true; namely, where the owner is also the manager. A study, based upon a mathematical model which assumed a single owner-manager, concluded:

[F]ixed-rate deposit insurance produces an incentive for the insured bank to take risk.

More precisely, ... a fixed-rate insurance scheme always results in more risk taking than would be observed under a "fair" variable-rate system-defined as one in which insurance premiums are set equal to the mathematical expectation of losses of the insurer.

Boyd, Deposit Insurance Premium Setting: Its Effect on Portfolio Allocations and Risk of Insured Institutions, in Proceedings of a CONFERENCE on BANK Structure ANd Competition 210, 210-11 (1983) (Fed. Reserve Bank of Chicago) (emphasis in original).

137. There is substantial evidence that de facto deposit insurance is greater for larger banks. See, e.g., E. Kane, supra note 106, at 2-3 (noting that it is harder to close larger banks due to the size of fund liability, the effects on confidence, and political fallout). The FDIC admits that there is a general impression that large banks are more fully protected:

As the use of assisted deposit assumptions has become more common and increased numbers of depositors and investors continue to be shielded from losses in large banking organizations, the public's perception of the relative safety of funds appears to have become altered. Many believe that no large American bank will be paid off even if it werc allowed to fail, and have acted aceordingly.

FDIC, supra note 58, at III-1. 
will often use size as a proxy for risk, charging large banks a lower interest rate for funds. ${ }^{138}$ This shifting of funds to large banks creates a number of inefficiencies. First, it encourages banks to expand their assets so that investors will perceive them as a large bank and thus protected by de facto insurance. ${ }^{139}$ To the extent that banks acquire lower quality assets in an effort to expand, their stability and that of the system are threatened. ${ }^{140}$ The government's potential deposit-insurance hability is increased, by both a reduction in the quality of acquired assets and the specter of a sudden withdrawal of funds that could result in a hiquidity crisis.

As a final point, the nondisclosure regime actually undermines the goal of a safe and sound banking systein. The allocation of funds according to bank size rather than inanageinent skill, coinbined with a lack of adequate information, increases the volatility of bank habilities. Given the fiduciary duty of some institutional investors to protect their funds, ${ }^{141}$ and the many investinent options available to such funds, ${ }^{142}$ managers are unlikely to leave them in a potentially risky bank. As one writer concluded:

Compounding this problem is the fact that even the sophisticated money markets have incomplete information concerning most banks operating in the market. Thus, the inability of the market to properly analyze the true condition of a bank makes it extremely vulnerable to rumors of trouble in individual banks. The market may therefore grossly exaggerate a particular problem confronting a bank and choose to deny the bank access to the market. ${ }^{143}$

The sudden flight of almost $\$ 10$ billion froin Contimental Illinois in the sixty days following erroneous press reports concerning a possible feder-

138. For example, after Franklin National was closed and merged, the $\mathrm{CD}$ rate for regional banks was 25 basis points higher than for money center banks. Gilbert, supra note 74, at 71. About $74 \%$ of uninsured funds are in banks with assets of $\$ 1$ billion or more. Id. at 70.

139. The bank may even decide that this is a relatively safe strategy, simce after attaining the magic asset size, perhaps $\$ 1$ billion, it will have regular access to short-term funds at a reasonable rate, thus allowing it to service the new assets.

140. This encouragement to grow in size runs counter to the long tradition in banking that large banks produce social disutility becanse of the threat of concentration of economic power. See K. COOPER \& D. FRASER, supra note 66 , at $36,42-45$.

141. See supra text accompanying note 100 .

142. D. Crane, R. Kimball \& W. Gregor, The Effects of Banking Deregulation (1983) (study prepared for Ass'n of Reserve City Bankers):

One important result of the new entrants and the introduction of product substitutes in the commercial banking market has been a substantial loss of bargaining power by banks relative to depositors and borrowers....

As the number of options has grown, and bank customers have become increasingly accnstomed to looking for service outside their normal banking relationships, customer loyalty and the bargaining power of banks have both decreased.

Id. at 56.

143. Homan, supra note 103, at 268. 
ally arranged purchase of the bank ${ }^{144}$ demonstrates the volatility of the funds and the importance of investing them on the basis of risk considerations, rather than size.

The nondisclosure regime also threatens safety and soundness by concealing and subsidizing mefficient bank risk taking. The subsidization reduces the risk costs of high-risk loans, increasing their previous low yield. Low-risk assets, such as money and Treasury bills ( $T$ bills), become less desirable to banks because they are relatively more expensive. ${ }^{145}$ Banks are thus imduced to weaken their asset portfohos and fund mefficiently risky enterprises that could not previously qualify for loans.

A bank with a rapidly deteriorating asset portfoho-hoping to reverse its misfortunes-may make riskier decisions without increasing its production of confidence. ${ }^{146}$ The divergence in the interests of owners and managers makes managerial decisions to "bet the bank" nnore likely where such actions miglit prevent losses that could cause a management shake-up or bankruptcy. ${ }^{147}$ If those asset-portfolio decisions are shielded from depositor review, as they are under the nondisclosure regime, depositors will not be aware of mcreased superrisk, and will not demand more confidence. Therefore, the bank will face the same current cost for funds despite its riskier conduct. Should depositors become aware of this risky conduct, through reporting of quarterly losses for example, the confidence produced may be imsufficient to prevent a bank run.

The economy's movement toward more speculative finance, where firms with insufficient cash flow to cover obligations assume new investments and near-imsolvent banks are encouraged to make riskier loans, mcreases financial fragility. ${ }^{148}$ This fragility feeds back into the banking

144. Continental Illinois Hearings, supra note 54, at 272-73, 275 (app. to statement of C.T. Conover, Comptroller of the Currency). The market had already been worried about Continental Illinois because of its large holdings of loans originating from the failed Penn Square National Bank. See id. at 258-59.

145. Cf. Minsky, supra note 92, at 100-01, reprinted in Hearings at 391-92. Euphoric expectations cause banks to consider the risk costs of projects to be less and thus make previously low-yield assets more profitable. Low-risk assets, such as money and $\mathrm{T}$ bills, become less desirable to banks, because they are relatively more expensive.

146. Merton, On the Cost of Deposit Insurance When There Are Surveillance Costs, $51 \mathrm{~J}$. Bus. 439, 448 (1978) ("II]f it is already substantially below the solvency level, then by increasing the volatility of its assets the bank will increase the likelihood of becoming solvent by the time of the next audit.'); Minsky, supra note 92, at 108, reprinted in Hearings at 399. Furthermore, given its deteriorating financial condition and the last-ditch nature of its risky-asset strategy, a near-insolvent bank would probably not produce extra confidence to cover for the significant possibility of losses.

147. It is doubtful that bank shareholders currently have enough information on bank portfolio quality to be aware of excessive risk taking by management. See supra notes $75-77$ and accompanying text. Even informed shareholders would be unable to control such managerial risk taking, especially in the situation of the near-insolvent bank, no matter the form of corporate organization. See infra notes 165 (publicly-held corporations), 166 (close corporations), and 167 (owner-manager firms).

148. "Once euphoria sets in, [financial institutions] accept liability structures-their own and 
system by increasing competition for funds, which raises interest rates, ${ }^{149}$ and by proliferating the layering of debt in the economy, which leads to a greater demand for refinancing. ${ }^{150}$ A downward spiral may then occur as near-insolvent banks fuel the nonbanking sector's speculative finance and that speculative finance erodes the quality of bank assets, which increases the number of problem banks. Should a number of near-insolvent banks collapse, those confidence levels that were suitable for depositors in a hedge-financing econorny would suddeuly become inadequate. This could cause depositors to reassess superrisk levels generally and precipitate a banking panic and an economic retrenchment from speculative finance. ${ }^{151}$

Despite this potential for systemic collapse caused in part by mefficient bank risk taking, the U.S. banking system appears deceptively robust. The ability of banks to rely upon X-confidence to satisfy depositor deinands for confidence allows the banking system to function at a seemingly stable equilibrium despite the asymmetrical availability of

those of borrowers-that in a more sober expectational climate, they would have rejected." Minsky, supra note 92, at 101, reprinted in Hearings at 392. The tendency of banks, facing competitive pressures, to follow the lead of other banks in the search for profitable assets inagnifies this effect. See supra note 6 (discussing this behavior in bank lending to foreign countries, REITs, and consumers).

149. See generally Minsky, supra note 92, at 100-03, reprinted in Hearings at 391-94 (discussing impact of increased demand for funds on interest rates and resulting depressive effects in soine sectors from "tight" inoney).

150. See id. at 115-16, 119-21, reprinted in Hearings at 406-07, 410-12; cf. Bianco, Playing with Fire, Bus. WEEK, Sept. 16, 1985, at 78, 80 (describing layering of debt in capital markets where, by purchasing a stock index future for a six percent downpayment and using it "as collateral for other purchases, leverage can be piled on leverage"). The phrase "layering of debt" refers to firms undertaking capital investments and increasing their debt because of euphoric expectations.

In an expanding economy, firms determine their ability to make debt payments based on euphoria-induced, cash-fiow projections from existing operations and newly undertaken projects. Minsky, supra note 92, at 114-15, reprinted in Hearings at 405-06. The greater the euphoria, the greater the likelihood that firms will becone speculative financing units; that is, have cash obligations exceeding receipts in some periods. See supra note 2 . Refinancing of debt, probably at higher interest rates due to demnand-pull effects, see supra note 149, will become necessary, thereby increasing the layering of debt and the dependence of the economy on stable financial markets. Money-market changes can lead to economic instability as projects, viable under previous interest rates, no longer have positive net present values, thus threatening the soundness of enterprises and their lenders, absent inflation or additional (and riskier) refinancing. See Minsky, supra note 1, at $150-51$.

151. See generally Minsky, supra note 92, at 123-24, reprinted in Hearings at 414-15 (discussing causes of systemic financial instability). As President Franklin Roosevelt observed during the Depression:

[Some bankers] had used the money entrusted to thein in speculations and unwise loans.

This was of course not true in the vast majority of our banks but it was true in enough of them to shock the people for a time into a sense of insecurity and to put them into a frame of mind where they did not differentiate, but seemed to assume that the acts of a coinparative few had tainted them all.

F.D. Roosevelt, Radio Address of Mar. 12, 1933, reprinted in E. SyMONS, JR. \& J. WhITE, supra note 13 , at 40 . 
information and the underproduction of confidence. Although depositors only demand a level of total confidence, society benefits from the production of some minimum amount of information and the assumption of risk by depositors.

Because they lack sufficient information to distinguish high-quality banks from low-quality banks, depositors judge the soundness of a bank, and thus determine the return they are willing to accept, by their view of the average soundness of all comparable banks. A "lemons process"152 occurs, where higher quality goods, unable to receive their full value, leave the market, causing the average quality of goods to fall further, until only the worst quality goods remain and the market collapses. However, existence of X-confidence induces higli-quality banks to remain in the market, thus creatimg a "lemons equilibrium." The governmental guarantee induces consumers to remain in the market despite the presence of lemons and to pay to all banks of seemingly high quality the fee demanded by the actual higl1-quality banks, thus keeping them in the market. ${ }^{153}$

The lemons equilibrium, however, can collapse easily as information or rumors circulate. Depositors demand the level of confidence associated with average risk. When disclosure of serious problems occur, all banks that were thought comparable become subject to runs. To the extent the market is able to differentiate the failing institution (for example, that Franklin National was on a reckless growtli strategy, U.S. National Bank of San Diego was riddled with fraud, Continental Illinois was plagued with Penn Square loans), there is less chance that depositors will mcrease their estimate of risk in the average bank. The existence of noninformation confidence, especially deposit insurance with its effect of diminishing the concern for liability and personal vigilance of depositors, allows the market to return to an equilibrium of sorts.

The present lemons equilibrium will be short hived without increases in X-confidence. In the short run, lemons will prosper simce their costs are less. In fact, depositors risk rewarding lemons by directing their funds to the large institutions which offer the highest returns, although

152. Ackerlof, The Market for "Lemons": Qualitative Uncertainty and the Market Mechanism, 84 Q.J. ECON. 488 (1970). For an application of this theory to financial intermediaries, see Leland \& Pyle, Informational Asymmetries, Financial Structure, and Financial Intermediation, $87 \mathrm{~J}$. POL. ECON. 1328 (1979).

153. An alternative explanation for the market not deteriorating could be that there are not enough lemons in the banking system to trigger a lemons process. See Campbell \& Kracaw, Information Production, Market Signalling, and the Theory of Financial Intermediation, $35 \mathrm{~J}$. FiN. $863,868-69 \mathrm{n} .9$ (1980). The large number of problem and failed banks, however, negates this possibility. See supra note 53. Furthermore, the widespread knowledge of failed banks combined with the dearth of information on the quality of other banks, could make a lemons process even more hikely absent deposit insurance because depositors might overestimate the incidence of lowquality banks. 
such returns may be the results of a risky-asset strategy. With increasing exogenous risks, the level of confidence will become even less stable. As the risk of losing money becoines evident from the increasing incidence of lemons, depositors inay be less willing to remain in the inarket and the lemons equilibrium more likely to deteriorate. Should such a deterioration occur, consuiners will demand increased levels of X-confidence to remain in the inarket and to continue to pay premium prices (by accepting relatively low interest rates) despite inountimg evidence that the banking systeln is rife with leinons. In a situation where X-confidence is pervasive, the equilibrium will consist of high-priced products of low-quality rather than low-quality, low-priced goods.

Stability in the banking system is presently purchased at the cost of inefficient risk taking and fragility in the economy. The current regulatory approach of preserving secrecy and increasing X-confidence hides the underlying problems but does not address them. The next subsection rejects the notion that regulatory changes im the nondisclosure regime are sufficient to prevent excessive speculation by banks.

\section{The Inadequacy of Regulatory Alternatives Within a Nondisclosure Framework}

The proposals offered for improving the nondisclosure regime will be unable to counter the four identified failures of the nondisclosure regulatory approach. These proposals include (1) risk-priced premiums, (2) minimuin capital standards, (3) banking-powers restrictions, and (4) country or sectoral lending limits.

This Comment has shown already that fixed-rate, $100 \%$ deposit insurance may lead to excessive risk taking by banks without signifcantly reducing the occurrence of bank runs. ${ }^{154}$ Although many commentators have proposed risk-priced deposit insurance, ${ }^{155}$ its success will depend on the accuracy of government risk assessments. In ideality, $100 \%$ deposit insurance would eliminate depositor runs, while riskpriced premiums would eliminate the subsidy for risk taking. Although it generally supports premiums related to risk, the FDIC has concluded that risk-priced premiums are infeasible. ${ }^{156}$ Furthermore, deposit imsur-

154. See supra notes 117-18 and accompanying text.

155. See, e.g., E. KANE, supra note 69, at 158-60; Bierwag \& Kaufman, A Proposal for Federal Deposit Insurance with Risk Sensitive Premiums, in ProceedINGs of A CONFERENCE ON BANK STRuCture AND CoMPETITION 223 (1983) (Fed. Reserve Bank of Chicago). Of course, publishing the risk-priced, deposit-insurance premiums would create a disclosure regime.

156. The FDIC concluded: 'The 'ideal system' with premiums tied closely to risk is sinply not feasible. Such a system would require the FDIC to be given an extreme amount of authority. Moreover, it would entail unrealistic data requirements and much more advanced risk quantification techniques than are currently imaginable." FDIC, supra note 58, at II-1; see Boyd, supra note 136, at 221 (doubting whether a government agency could correctly set risk premiums). 
ance premiums inevitably will lag behind risk levels. Factors such as regulators' lack of political will and bureaucratic inertia and banks' incentive to create innovative financial instruments to evade regulatory controls will cause this lag. ${ }^{157}$ These forces will prevent the nondisclosure regime from fully eliminating government subsidization of bank risk taking. The more regulators underprice deposit insurance, the greater the potential social benefits froin depositors also pricing bank risk taking. While risk-related premiums would eliminate some of the subsidization of risk taking, they alone are insufficient to fully address the failures of the nondisclosure regime. Depositor discipline, which can threaten a bank with higher costs and, in the extrene, failure, is needed as an additional clieck on bank risk taking. ${ }^{158}$

Second, reliance on minimum capital requirements will not eliminate the instability of the nondisclosure regime. In theory, increases in capital can preserve bank soundness by providing a buffer to absorb losses and by putting more owners' equity at risk, which increases the cost to them of excessive speculation. ${ }^{159}$ Minimum capital requirements, however, could not be effective without additional disclosure. Not only do uninformed investors risk directing funds to banks that are not well managed, de facto deposit insurance provides an incentive for investors to buy shares of large banks, despite uncertainty over the quality of management or the risks in their portfolios. ${ }^{160}$ As long as uninsured depositors lack information on the size of probable loan losses, they cannot determine the adequacy of capital buffers. Even with minimum capital requirements, banks still would be vulnerable to a loss of confidence and runs caused by rumors and indications of problems because uninsured depositors may not wait to see if capital cushions are sufficient. ${ }^{161}$

157. See supra note 133; see also Kane, Policy Implications of Structural Changes in Financial Markets, 73 Am. Econ. Rev. PAPERS AND Proceedings of the Am. Econ. Ass'N 96, 98 (1983) (attributing regulatory lag in responding to financial innovation "to asymmetric information, to the short horizons of pohitical appointees, and to the nonprofit orientation and characteristic slowness of bureaucratic decisiou making").

158. See infra text accompanying notes 210-17.

159. Final Rulemaking Revising Minimum Capital to Asset Ratios, 50 Fed. Reg. 16,057, 16,059 (1985) ("The [Federal Reserve] Board has long held that adequate capital is a critical factor in helping a banking institution wcather financial adversity and in promoting the safety and soundness of the banking system.") (establishing ratios of 5.5\% (primary capital) and 6\% (total capital)).

Bank share values can be viewed as "put" options, in that the shareholders can choose to allow the bank to go bankrupt and, in effect, exercise their option to sell. The lower the put value, the more likely owners are to exercise their option. Merton, supra note 146, at 447-48; see R. BREALEY \& S. MYERS, supra note 4, at 437.

160. The reason is that large banks are more likely to receive governmental aid to avoid liquidity crises and possible failures. See supra text accompanying notes 137-40. Systemic fragility is increased by the misdirecting of investments to large, but poorly managed banks. See supra text accompanying notes $141-44$.

161. See Homan, supra note 103, at 268. 
A fully informed capital market ${ }^{162}$ would not provide sufficient controls over bank risk taking, absent depositor discipline. Although minimum capital standards might induce some banks to constrain risk taking to avoid falling below minimum capital levels and having to reenter capital markets, ${ }^{163}$ such standards would not prevent excessive risk taking by near-insolvent banks. As previously argued, manageinent of near-insolvent banks are pressured to take risks and "bet the bank;"164 the prospect of reentering capital inarkets is meaningless if such bets fail. Moreover, in large, publicly held corporations the theory of informed shareholders controlling bank inanagers fails in practice. ${ }^{165}$ In close corporations, the theory is equally untenable as it iguores the vulnerability of minority

162. The FHLBB has suggested such an alternative. FHLBB, AGENDA FOR REFORM 135 (1983) (suggesting "100 percent deposit insurance coverage, coinbined with full disclosure" and regulatory supervision).

Another proposal is that federal regulators require banks to issue subordinated debt, as well as equity securities, to meet a higher minimum-capital requirement. E.g., FDIC, supra note 58, at III-7 to III-9. Given the agency costs preventing effective control of management by voting stock, see infra notes 165-66 and accompanying text, it is hard to sce how these long-term debtholders will influence manageinent, once they have purchased the debt. On the other hand, short-term debt could discipline bank risk taking by forcing banks to enter capital inarkets often, but such debt would have the same unstable characteristics as uninsured deposit instruments such as 60-day CD's.

163. Minimum capital standards could have the opposite effect. Higher capital requireinents reduce the amount of dollars for investing and producing returns, thus some banks might increase risk taking in order to maintain earnings per share. The Federal Reserve's recent proposal to revise its ininimum capital standards to account for categories of asset risk was motivated in part by banks increasing their risk taking to meet the minimum capital standards. See Supplemental Adjusted Capital Measure, 51 Fed. Reg. 3976, 3976-77 (proposed Jan. 31, 1986).

164. See supra text accompanying notes 146-47.

165. Commentators have long recognized the separation of ownership from control in the publicly held corporation. A. Berle \& G. MEANS, THE MOdern Corporation AND PRIVATE PROPERTY 3 (1932) ("The property owner who invests in a modern corporation so far surrenders his wealth to those in control of the corporation that he has exchanged the position of independent owner for one in which he may bccome merely recipient of the wages of capital."). This separation prevents even fully informed shareholders from stemming the tendency of management of nearinsolvent banks to speculate excessively because "the interests of owner and of ultimate manager may, and often do, diverge, and ... many of the checks which formerly operated to limit the use of power disappear." Id. at 6 (discussing separation in general corporate context); see Brudney, Corporate Governance, Agency Costs, and the Rhetoric of Contract, 85 Colum. L. REv. 1403, 1410 (1985); Buxbaum, The Internal Division of Powers in Corporate Governance, 73 CALIF. L. REv. 1671, 1732 (1985) (attributing decline in shareholder rights to "traditional enabling-law philosophy, excessively aggressive efficiency rationales, and powerfully focused managerialist strategy").

Shareholders have little, if any, control over the selection and compensation of managers, undermining even this indirect control over management risk taking. See Brudney, supra, at 141216 (arguing that shareholders are unable to determine managerial arrangements, have a passive role in choosing among directorial nominees, and have little information for making an informed vote or discerning the terms of managerial employment contracts and legal duties); Hetherington, Fact and Legal Theory: Shareholders, Managers, and Corporate Social Responsibility, 21 STAN. L. REV. 248, 255 (1969) (developments such as "[t]he lack of shareholder control over the selection of management and over corporate policy ... have eliminated the attributes of ownership held by the shareholders"). But see Ross, Disclosure Regulation in Financial Markets: Implications of Modern Finance Theory and Signaling Theory, in Issues IN FinanCial REgulation 177, 183-88 (F. Edwards ed. 1979) (theorizing that management has an incentive to signal good news to 
shareholders' investınent to capture by the inajority for use to subsidize bank risk-taking decisions. ${ }^{166}$ Even in the paradigm case of a single owner-manager, the availability of deposits that are not actuarially risk priced will subsidize (and thus induce) excessive speculation by nearinsolvent banks. ${ }^{167}$ Without depositor discipline, near-insolvent banks

shareholders, who will link managerial compensation with the corporation's performance and will monitor management for self dealing).

Nor will reliance on management's supposed desires to maintain share prices adequately protect shareholders' interests. Compare Brudney, supra, at 1423-26 (arguing that ability to purchase or sell shares does not give imvestors power to pohice management due to (1) the bundling of many attributes of the firm in the stock price and (2) the inaccuracy of that price as a reflection of company value), and Coffee, Market Failure and the Economic Case for a Mandatory Disclosure System, 70 VA. L. REv. 717, 722 (1984) (noting management's incentive to hold down share values to pursue a leveraged buyout as an example of the divergence in shareholders' and management's interests), with Hetherington, supra, at 263-72 (arguing from a Galbraithean perspective that management desires higher stock prices, because high prices reflect on management's ability and usually coincide with growth).

Although institutional investors have asserted their role in some recent takeover battles, see, e.g., Cohen \& Rose, Unocal Is Seen Gaining on Mesa in Proxy Fight, Wall St. J., May 10, 1985, at 5, col. 3 (e. ed.) (institutional imvestors forced Unocal management to go through with an offered repurchase of $30 \%$ of the outstanding stock at a premium in return for their opposing a takeover bid); Council of Institutional Investors Is Becoming a Force To Be Reckoned with in Corporate Takeover Plotting. Am. Banker, Oct. 29, 1985, at 40, col. 1 (discussing the Council of Institutional Investors, which consists of 131 individual funds with combined assets exceeding $\$ 130$ billion, and its role in Phillips Petroleum Company's attempt to ward off a hostile takeover bid), they have yet to demonstrate the proclivity and ability to influence nonstructural, managerial decisions, such as the amount of risk taking by banks. See Brudney, supra, at 1412 n.23.

166. For instance, the controlling shareholders ean gamble witl the minority sliareholders' investment and avoid the losses from the default of high-risk assets by "squeezing out" the minority and capturing any profits, which might otherwise be insufficient if they had to be divided amongst all owners. One commentator described the power of the majority to expropriate an unfair share of the close corporation's profits as follows:

[I]t is not unreasonable to suppose that the situations involving unprotected, and therefore potentially exploited minorities in close corporations, are the rule rather than the exception. ...

....

... [T] le right of the majority to control the enterprise achieves a meaning and has an mupact in close corporations that it has in no other major form of business organization under our law. Only in the close corporation does the power to manage carry with it the de facto power to allocate the benefits of ownership arbitrarily among the shareholders and to discriminate against a minority whose investment is imprisoned in the enterprise.

Hetherington, Special Characteristics, Problems, and Needs of the Close Corporation, 1969 U. ILL. L.F. 1, 18-19, 21; accord 2 F.H. O'NEAL \& R. THOMPSON, O'NEAL's OPPRESSION OF MiNORITY SHAREHOLDERS, $\S 10: 03$ (2d. ed. 1985); see $1 \& 2$ id. at $\S \S 3: 01-6: 10$ (detailing a variety of squeezeout techniques imvolving inter alia dividends, employment, sale-of-control transactions, and mergers).

Commentators have argued that the law should enforcc the actual bargain of the parties, including the omission of protections for minority sliareholders. See Easterbrook \& Fischel, Close Corporations and Agency Costs, 38 STAN. L. REv. 271, 284-90, 301 (1986). This argument, however, does not deny that squeeze outs subsidize risk taking by many closely held banks. Given that minority shareholders of near-insolvent banks would also favor a bet-the-bank strategy, see supra text accompanying notes 167-68, the solution to concerns over risk taking is to enlance depositor diseipline.

167. Boyd, supra note 136, at 210-11 (using a mathematical model to demonstrate that under the present deposit insurance system a single bank owner/manager will undertake exeessive risk); see 
will continue to garner deposits and speculate excessively, thereby increasing the fragility of the econoiny and the threat of bank runs. ${ }^{168}$ Mininuin capital standards, while useful for absorbing loan losses, fail to address the cause of banking-induced economic instability-a flow of deposits for investınent by banks not disciplined by depositors.

Third, attempts to constrain bank risk taking by limiting banks' perinissible activities will not remedy the instability of the nondisclosure regime and niay worsen the health of banks. The increased competition in financial services has caused banks to seek new powers to operate in areas previously considered outside the realm of banking. ${ }^{169}$ If the regulatory regime does not allow banks to coinpete effectively with other financial institutions, banks may lose depositors' funds. ${ }^{170}$ As nonbank financial institutions encroach upon the traditional territory of banks, ${ }^{171}$ worsening profit inargins could increase banking instability. ${ }^{172}$ The inarket discipline from uninsured depositors coinbined with regulatory discipline, however, could enable banks to safely and soundly exercise new powers and to increase public confidence.

Finally, proposals to limit bank risk taking by setting percentile limits on loans to particular sectors, such as foreign countries ${ }^{173}$ or agricul-

Merton, supra note 146, at 448 . Even with risk-priced deposit insurance, if there are lags in readjusting the premiuns, see supra text accompanying note 157 , owners will have an incentive to take a bet-the-bank strategy in a final bid to reverse their misfortunes.

168. See supra text accoinpanying notes 145-51.

169. A striking example of this push for expanded powers is Citicorp's application to the Federal Reserve to operate a securities-underwriting subsidiary under the "engaged principally" language of $\S 20$ of the Glass-Stcagall Act, 12 U.S.C. $\S 377$ (1982). See Albert, Citicorp Strikes a New Blow In Battle with Securities Firms, Am. Banker, Aug. 22, 1985, at 2, col. 1; see also B. Meyer, The Glass-Steagall Act: End of an Era? 35-50 (Apr. 29, 1986) (unpublished paper subınitted to the Nat'l Center on Fin. Serv.) (discussing attempts of banks to expand underwriting, privateplacenents, and security-affiliate activities). Morgan Guaranty's threat to give up its commercialbanking charter to becoine an investınent bank is a more dranatic, but soinewhat less credible, response to bank-powers restrictions. See Banks May Drop Charters, Become Securities Firms, Wall St. J., Apr. 9, 1986, at 6, col. 2 (w. ed.).

170. See Wall \& Eisenbeis, Risk Considerations in Deregulating Bank Activities, Econ. REv., May 1984, at 6, 6 (concluding that deregulation of bank activities "poses no threat to the stability of the financial system but that failure to deregulate does pose such a threat"); see also Note, The Demise of the Bank/Nonbank Distinction: An Argument for Deregulating the Activities of Bank Holding Companies, 98 HARv. L. Rev. 650 (1985).

171. See supra note 129. For a failed attenpt by the Federal Reserve to check this encroachinent, see Board of Governors v. Dimension Fin. Corp., 106 S. Ct. 681 (1986) (invalidating attempt to regulate as banks nonbank banks offering services that are the functional equivalent of traditional banking services, even though the firms do not satisfy the narrow, technical definition in \$2(c) of the Bank Holding Coinpany Act of 1956, 12 U.S.C. \$ 1841(c)) (1982).

172. D. CRANE, R. Kimball \& W. GREGOR, supra note 142, at 106; see supra note 128.

173. See, e.g., Note, The Policies Behind Lending Limits: An Argument for a Uniform Country Exposure Ceiling, 99 Harv. L. Rev. 430 (1985); Langley, U.S. Expected To Propose Cap On Thrift Loans, Wall St. J., June 9, 1986, at 5, col. 1 (w. ed.) (discussing possible changes in lending linnits to reduce thrifts' exposure to large real estate loans). The current per-borrower lending linnit for national banks is discussed supra at notes $34-35$ and aecoinpanying text. 
tural conipanies, will not guarantee stability. Even if such ninimumdiversification proposals were pohitically feasible, ${ }^{174}$ they would not necessarily reduce borrower credit risks. ${ }^{175}$ Nor would such proposals necessarily direct funds to well-nianaged banks. Such enforced mininiunı diversification nray be desirable, but without depositor discipline it is not a sufficient solution to inefficient bank risk taking.

\section{An Emerging Role for Banking Disclosure Regimes}

Disclosure is necessary to encourage the inovement of funds accordmg to risk considerations. $\mathrm{N}$-confidence inspires public confidence due to favorable conditions in the bank. An increase in N-confidence represents an unanibiguous reduction of risk in the bank. ${ }^{176}$ An increase in Xconfidence inspires public confidence but does so not because of a decrease in the bank's risk taking, but because of an increase in the amount of risk covered by the government or another third party. ${ }^{177}$ When the costs of that riskiness are separated from the decisions to

174. If uniform limits were applied irrespective of the economic and political stability of the foreign country, sucl proposals would deny banks access to good lending opportunities. $\mathbf{R}$. Weintraub, International lending by U.S. Banks: Practices, Problems, and Policies 22 (1983). On the otler liand, if limits were tailored to individual countries, they could alienate allies identified as poor credit risks or denied access to U.S. bank loans. Proposed Solutions to International Debt Problems: Hearings on S. 502 and S. 695 Before the Senate Comm. on Banking, Housing and Urban Affairs, 98th Cong., 1st Sess. 23, 32 (1983) (joint memorandum of P. Voleker, Chairman, Bd. of Governors, Federal Reserve, C.T. Conover, Comptroller of the Currency, and W. Isaac, Cliairman, FDIC, dated Apr. 7, 1983) [hereinafter cited as Joint Memorandum]; R. WEINTRAUB, supra, at 23.

175. One writer has invoked the capital-asset pricing model to suggest that country limits could diversify loan-portfolio risks by limiting the number of loans whose returns are positively correlated. Note, supra note 173, at 436; see id. at 441 . The possibility of diversification does not ensure efficient risk taking, because lending limits alone will not force banks to determine the effects of the loans on their portfolio nor to perform the careful credit-risk analysis required to set efficient returns on loans. See supra notes 4-5. The limited uumber of ligh-quality lending opportunities, see supra note 6, and the lack of active trading markets, see supra note 4, discredit the assumption that "spreading eggs into many baskets" witlout the careful analysis of borrower-specific risks will result in efficient risk taking. On the other liand, depositor discipline based on disclosure of concentrations and classifications of the portfolio, as a whole and within concentrations, would penalize banks not diversifying those risks. See infra notes 210-17.

As an additional criticism, the extent to which foreign-lending risks are diversifiable is unclear. There is some evidence that mucl of the risk from foreign lending is country-specific risk and thus diversifiable. Goodman, Diversifiable Versus Non-diversifiable Risk in LDC Lending, in Proceedings of a Conference on Bank Structure and Competition 108, 122-23 (1981) (Fed. Reserve Bank of Chicago). Country limits, however, may not diversify a significant amount of risk because default risks from debtor nations' lack of political will to meet debt payments may be highly correlated. See id. at 117. For example, Federal Reserve Chairman Voleker "warned that individual debt cases 'are interrelated, and if the Mexican situation can't be liandled in an orderly way, it makes it more difficult to liandle' debt problems in Argentina, Nigeria, Venezucla and other debtor countries." Pine, supra note 61 , at 7, col. 4 .

176. This assumes that depositors correctly interpret the significance of the $\mathrm{N}$-confidence and that remedies for fraud and otler actions deter management efforts to misinform.

177. Of course, risk pooling reduces risk bearing costs, L. FRIEDMAN, supra note 86, at 206, but 
undertake it and support it, as is currently the case, bank risk taking will invariably increase. ${ }^{178}$ Information, combined with an actual possibility of bank failure and depositor loss, is essential to discipline risk taking because it allows the market to ensure that benefits exceed the actual costs.

Federal regulators have begun to realize that the increasing risks in banking necessitate market discipline of banks by informed, uninsured depositors. The FDIC recently adopted (and then postponed the implementation of) regulations requiring the release of names of those banks against whom it issued final orders in statutory enforcement actions. ${ }^{179}$ In justifying the pohicy, it recognized the increasingly important regulatory role of information, arguing that:

[G]reater reliance on market discipline is preferable to the introduction of an excessive and extensive system of regulatory controls over the activities of banks. ... [T] he banking public needs information concerning the banks with which it conducts or may conduct its business in order to properly evaluate the level of risk that will be encountered in dealing with specific banks. ${ }^{180}$

The OCC is currently mvolved in ruleniaking proceedings to mandate disclosure of certain information to depositors and shareholders in annual, quarterly, and current reports. ${ }^{181}$ Neither of these proposals, however, provides for inandated disclosure of enough relevant information. For exainple, neither requires disclosure of examination-type data regarding asset quahity.

Assuming that the other neasures recommended in this Comment are mstituted to put depositors' funds at risk and allow banks to fail $\mathrm{m}$ an orderly manner, ${ }^{182}$ disclosure of relevant information would decrease the volatility of the banking system. Safety rather than size thus would become a crucial determinant of the flow of funds. Risky assets would become less attractive to banks, since their potential costs to depositor confidence would not be subsidized by deposit insurance. Expansion for the sake of de facto deposit insurance also would be less prevalent. The

the chance of default remains the same, Bianco, supra note 150, at 86,90 ("[A] guarantee doesn't eliminate credit risk, it merely shifts responsibility for an obligation.").

178. This is a classic moral-hazard situation. See supra note 118. The fact that social costs exceed the private costs of the risky conduct will cause banks to inefficiently increase their riskiness. L. FRiedman, supra note 86 , at 215.

179. Disclosure by the FDIC of Statutory Enforcement Actions, 50 Fed. Reg. 20,609 (1985), postponed by 50 Fed. Reg. 52,557 (Dec. 24, 1985).

180. Disclosure by the FDIC of Statutory Enforcement Actions, 50 Fed. Reg. 7220, 7220 (proposed Feb. 21, 1985), adopted in 50 Fed. Reg. 20,609 (1985), postponed by 50 Fed. Reg. 52,557 (Dec. 24, 1985).

181. Disclosure of Financial and Other Information by National Banks, 50 Fed. Reg. 45,372 (proposed Oct. 30, 1985) (to be codified at 12 C.F.R. pt. 18).

182. See infra text accompanying notes 184-92. 
banking system would be less vulnerable to sudden shifts of liabilities, because informed depositors would reallocate funds to well-run banks and would be less likely to rely on rumors inconsistent with the disclosed information. Part III presents the parameters of a possible disclosure regime, as well as the justifications for mandated-disclosure requirements.

\section{III.}

\section{Banking Disclosure Regimes for ApProaching LENDING RISKS}

This Part considers alternative disclosure regimes for addressing the problem of lending risks and bank failures. The current nondisclosure regime's inability to prevent fragility in the banking systein already has been shown. ${ }^{183}$ A more effective approach to avoiding financial fragility involves a tripartite program: (1) uninsured depositors inust be placed at risk; (2) banks inust be allowed to fail without disrupting the financial systein; and (3) information on asset quality must be disclosed.

First, if a disclosure regime is to be effective, uninsured depositors must be put at risk. As long as uninsured depositors know that the federal government will bail thein out, they will have little incentive to use information. The less information depositors use in a disclosure regime the more likely their behavior will acquire the undesirable characteristics of a nondisclosure regime.

To avoid this problem, de facto deposit imsurance inust be reduced. A possible approach might be for the FDIC to use a inodified payoff system whenever it needs to suspend or takeover an institution. ${ }^{184}$ For example, the FDIC could reimburse uninsured deposits at no more than seventy percent of their value, unless liquidation of the failed bank's assets resulted in a greater recovery. Furthermore, techniques of avoiding de jure limits on deposit insurance, such as the brokering of deposits in insurable blocks, ${ }^{185}$ should be prohibited. These methods increase de jure insurance coverage beyond what is needed to cover those relying on

183. See supra text accompanying notes 132-51.

184. FDIC, supra note 58, at III-4 to III-7 (discussing two modified-payoff proposals, one in which the FDIC would advance dollars to uninsured depositors towards yet-unsatisfied claims, based on its estimate of expected recovery from liquidating the bank's assets, and another resembling coinsurance, wherein only a percentage of uninsured depositors' funds above $\$ 100,000$ would be guaranteed). Effective market discipline will not oceur if uninsured depositors believe that the FDIC is unwilling to enforce a modified-payoff rule for large-bank failures. See Belluck, Continental Illinois Rescue May Doom FDIC Plan to Share the Insurance Risk, 16 NAT'L J. 1521, 1521.22 (1984).

185. FDIC, supra note 58, at III-13 (arguing that "the activities of such brokers must be controlled as an integral part of any risk-sharing proposal"); Silverberg, Restricting Brokered Deposits, 3 Housing FiN. Rev. 99 (1984). But see Seward \& Zaitzeff, Insurability of Brokered Deposits: A Legislative Analysis, 39 Bus. LAw. 1705 (1984) (arguing that brokered deposits are 
a withdrawal strategy. This reduces the number of economic actors that otherwise would follow a nionitoring strategy and thus discipline bank portfolio decisions. ${ }^{186}$

The second elenient of the proposal involves a policy of allowing banks to fail without jeopardizing systemic stability. While failing or insolvent banks should be allowed to fail or be merged into sound institutions, ${ }^{187}$ the threat of failure should encourage weak banks to use the period between disclosure reports to take steps to improve bank conditions. The disclosure of these efforts should strengthen the subsequent report and inspire depositor confidence. For exanıple, a bank might fornuulate plans for additional capitalization or obtain approval of major creditors or regulators for restructuring efforts. ${ }^{188}$

In order to minimize the impact of a failure on the banking system, the Federal Reserve could extend lender-of-last-resort facilities to all sound banks temporarily threatened by the ripple effects from a failure. ${ }^{189}$ This policy would reduce the economic disruptions caused by sound banks prematurely hiquidating assets at a loss or accelerating loans in order to increase hiquidity to meet withdrawal denrands of depositors. ${ }^{190}$ On the other hand, where relationships allow participating informed banks to set interest rates to reflect the risks involved, such as correspondent relationships or transactions involving CD's or federal

consistent with the purposes of federal deposit insurance and their restriction is contrary to present statutory language).

186. The elimimation of brokering activities could result in some of the previously insured funds being shifted to other investments. See Seward \& Zaitzeff, supra note 185, at 1713. This is not, however, a telling objection. The outfiow of deposits would indicate that the returns offered were insufficient given the riskiness of banks. This outflow of funds both disciplines bank risk taking and improves the efficiency of financial markets by removing the government subsidy which favors bank deposits and distorts investors' risk-and-return calculations.

187. Shareholders and uninsured depositors of failing or insolvent banks should suffer losses in any FDIC-arranged merger or hiquidation. For example, in consideration for bailing out Continental Illinois, the FDIC became an eighty percent owner of the bank with a possibility of increased ownership stake depending on the size of actual loan losses. Permanent Assistance Program, supra note 54, at 7.

188. Problem banks are currently using these sorts of measures to prevent failure. See, e.g., McCoy, Hawkeye, Creditors Agree on Basic Plan To Restructure Firm's $\$ 100$ Million Debt, Wall St. J., Apr. 9, 1986, at 7, col. 1 (bank holding company announced at annual shareholder meeting the restructuring of $40 \%$ of its debt as preferred stock); Hughes, Financial Corp. of America Reports Rise In Problem Loans Despite Its Forecasts, Wall St. J., Apr. 1, 1986, at 2, cols. 3-4 (accountants gave struggling thrift holding company unqualified opinion, because thrift received a letter from the FHLBB, which it included in its SEC filing, stating the FHLBB's (1) support for the thrift's efforts to restructure its balance sheet and (2) intent to make available longer term advances).

189. For a description of a proposal to allow the first large bank to fail but prevent all subsequent large-bank failures for the next two years, see Mayer, supra note 109, at 859-60. The ripple effects from a bank failure are discussed supra at text accompanying notes 122-26.

190. This policy would allow banks to avoid taking losses on their asset portfolios due to transient declines in the values of some assets. Also, it would prevent a contraction of the money supply from banks accelerating payments on outstanding loans, partially reversing the depositexpansion process, see supra note 9. 
funds, the benefits should not extend to cover such losses. ${ }^{191}$ In such instances, the Federal Reserve should make loans from the discount window against a bank's eligible collateral valued at its market price. A bank would be mehigible for such loans if because of avoidable losses it had insufficient assets to support thein. The availability of the lender-oflast-resort facilities, as qualified, would stem the spread of bank failures without undermining inarket discipline, because disclosure would inform depositors that only sound banks were being extended these benefits. ${ }^{192}$

Finally, disclosure is essential for the successful operation of the first two prongs of the regulatory approach urged by this Coinment. Disclosure enables uninsured depositors to select sound banks for transacting business, and the market force that they exert will cause unsound banks to fail and deter sound banks froin inefficiently taking risks. The question remains whether that disclosure should be voluntary or inandatory. The next Section analyzes these regulatory strategies using the confdence-production model of banking presented in Part II.

\section{A. Market Failures Will Undermine Voluntary Disclosure}

In a recent policy statement, the FDIC advocated voluntary disclosure by banks of their condition and performance. ${ }^{193}$ This policy would allow banks to decide what data to disclose, but applies only to "information that is publicly available," so that it would not give depositors access to examination data on loan quality. ${ }^{194}$ This policy does not go far enough. Many of the institutional investors already use this available information. ${ }^{195}$ The FDIC itself has noted that large depositors lack information on loan quality, ${ }^{196}$ and voluntary disclosure of currently available information will not remedy this deficiency.

Even if these regulatory barriers to disclosure were removed, a voluntary-disclosure regime would produce insufficient disclosure. While banks with favorable examination data inight disclose the results of those examinations, ${ }^{197}$ banks with poor exanination data would have little

191. See infra note 230 and accompanying text.

192. This approach contrasts with the general perception that services are currently available based on bank size rather than condition, which frustrate the opportunities for market discipline. See supra text accompanying notes 137-40.

193. 49 Fed. Reg. 26,809 (proposed June 29, 1984) (proposing to "notify depositors and creditors of insured banks and thrifts of information that is publicly available and to encourage the public to use that information when making decisions regarding the placement of their funds").

194. Id. at 26,809-11.

195. See supra text accompanying note 74 .

196. See supra text accompanying notes 75-77.

197. See Wooden \& Paluszek, Disclosure Needs of Financial Analysts: Large Bank Holding Companies, ECON. REV., Nov. 1983, at 77, 78 (noting some regional banks' "self serving" voluntary disclosure of "significant details" about their international lending portfolios in 1982 after concerns were raised over foreign lending by money-center banks); Zweig, Big Banks Disclose More About 
incentive to do so. The distribution by strong banks probably would be insufficient to counter the tendency of banks to undersupply confidence due to their consideration of only the internalized benefits from confidence production.

A voluntary-disclosure regime will probably produce not only too hittle, but also confusing and nonuniform nuformation. Lower quality banks have an incentive to produce confusing information to frnstrate the ability of depositors to differentiate sound institutions from lemons. ${ }^{198}$ By using atypical reporting formats and periods, banks could prevent effective comparison without technically misnuforming depositors. ${ }^{199}$ If banks' deposit costs are based on average risk in the banking system, then sound banks wonld have an economic incentive, equal to the expected lower amount that they wonld have to pay for deposits, to provide information to distinguish themselves from average or lower quality banks. Lower quality banks, however, wonld have an offsetting economic incentive to prevent effective coinparisons. The leinons equilibrium could prevent even this state of confusion, because all banks could earn the returns that depositors normally pay only to high-quality banks. Thus, at most, low-quality banks would produce misinformation, since they have everything to lose whereas high-quality banks have nothing to gain. These incentives probably wonld prevent voluntary disclosure from inducing banks to produce sufficient information for effective market discipline.

The projective nature of asset-quality data also may prevent a voluntary-disclosure regime froin producing useful data. It wonld be costly for depositors to verify this information and remedies for fraud would be less useful, because the data is comparable to a projection and thus cannot be easily proven false. These costs would cause depositors to demand and

Risks in Annual Reports, Wall St. J., Mar. 6, 1986, at 16, col. 3 (e. ed.) (reporting that three large New York banks provided more information on off-balance-sheet activities, such as currency swaps and loan commitments, in response to "what they viewed as exaggerated investor concern").

198. Campbell \& Kracaw, supra note 153, at 868 (overvalued firms have an incentive to misrepresent themselves as undervalued firms).

199. The SEC recognized this problem in the reporting of data on nonperforming loans, when it amended its disclosure rules for bank holding companies, known as Guide 3, to disallow use of different criteria and presentations, even if the substituted form "more effectively identifies and communicates the present risk elements." Amendments to Guide 3, 48 Fed. Reg. 37,609, 37,610 (1983) (to be codified at 17 C.F.R. pt. 231). The SEC recognized that "uniformity in the presentation of this data, and thus comparability among registrants, is important to investors." Id.; see Easterbrook \& Fischel, supra note 65, at 697 (market might not lead to optimal disclosure, because "comparative data would be underproduced because of the inability to charge for it"). The FDIC, on the other hand, sees this lack of uniformity (and overlooks the concomitant lack of comparability) as a benefit: "[D]epositors and other creditors should have the flexibility to determine the nature and method of dissemination of information appropriate for the bank's or thrift's size and operation. The adequacy of the information received from each institution will then be judged by its users." 49 Fed. Reg. 26,809, 26,810 (proposed June 29, 1984). 
use this data less, which would thus reduce its utility. Given the incentive to misinform and the difficulty of verification, for a voluntary-disclosure regime to provide useful information, some sort of guarantee by the government or a third party would be needed.

Competitive market forces would be unable to correct for inadequate disclosure under a voluntary-disclosure regime. Problems of misinformation, possible lack of comparability, and unascertainable rehability would reduce depositor's use of data on asset quality. Without confidence in the utility of the information, depositors would not be able effectively to exert market discipline. Furthermore, a bank could defuse depositor demands for disclosure by claiming that such disclosure would reveal the bank's investment strategy and threaten profits available for interest and dividend payinents. ${ }^{200}$ Depositors would be unable to distinguish between those banks that did not disclose to protect valuable business opportunities and those attempting to hide bad decisionmaking.

The choice between disclosure regimes is not simply a binary choice between a purely voluntary and mandatory regime; rather, there are inany possible regimes that coinbine voluntary disclosure with regulatory requirements. Regulations regarding formatimg, reporting periods, accounting primciples, coinpleteness, staleness of data, and certification requirements could be employed to enhance the rehability of this data. Even impleinentation of these regulations would not guarantee effective depositor discipline because of the previously discussed ability of banks to defuse depositor pressures for information. For a voluntary-disclosure regime to effectuate depositor supervision, it would quickly approach mandated disclosure with an inevitability that causes one to question the viability of the concept of voluntary disclosure.

\section{B. A Mandated-Disclosure Regime Will Maintain Confidence and Stability}

A mandated-disclosure regime would remedy the market's inability to produce adequate levels of confidence. Under this regime, the OCC, FDIC, and Federal Reserve could require insured banks to increase their production of $\mathrm{N}$-confidence by providing information that could be used to check rumors, distinguish high-quality banks from low-quality banks, and deter excessive risk taking by banks. Of course, any mandated-disclosure regime should be gradually phased in to allow banks to alter their lending policies and correct for existing problem loans in an orderly mamier.

200. See Easterbrook \& Fischel, supra note 65, at 685-86; cf. supra note 6 (discussing the tendency of banks to follow the lead of other banks into new markets). For an argument that the possible loss of profit from disclosure will not affect bank's behavior and thus not cause social losses, see infra text accompanying and following note 238 . 
The three federal banking regulatory authorities could promulgate uniform regulations requiring banks to produce quarterly and certified annual reports on bank condition. ${ }^{201}$ To facilitate comparability, the regulators should require that the data reflect bank condition on a specific date for each quarter. Federally msured banks would be required to distribute the reports to shareholders and uninsured creditors of record as of a specified date and make them generally available to the public upon request. ${ }^{202}$ To reduce reporting burdens, the disclosure requirements could be incorporated into existing Call Reports.

Depositors should have access to the information that bank regulators have found useful for their supervisory functions. To that end, banks should be required to disclose examination-type data, such as the amount and percentage of the loan portfolio that is classified, including a breakdown by classification, country, and economic sector. ${ }^{203}$ Banks should also be required to report the percentage and amount of previously disclosed classified loans where the classification changed in the current period. ${ }^{204}$ Other required disclosure should include suminary financial and asset-quality statistics for the last few reporting periods, pending or resolved regulatory enforcement actions, disagreements with accountants, and material changes in the bank's condition. ${ }^{205}$ In addition to the above data, the aunual report should also include a narrative statement by manageinent describing the quality of the bank's asset portfoho, hquidity position, and hability and capital structure, as well as an

201. Publicly held banks currently have to file quarterly and annual reports. See, e.g., 12 C.F.R. $\S \S 11.301, .304$ (1986) (OCC).

202. These reports only need be distributed to uninsured depositors to effectuate market discipline. The OCC has proposed that all national banks distribute quarterly and annual reports containing financial and narrative data. Disclosure of Financial and Other Information by National Banks, 50 Fed. Reg. 45,372 (proposed Oct. 30, 1985) (to be codified 12 C.F.R. pt. 18). These reports, however, will not contain information on loan classifications, see id. at 45,379 (no unauthorized disclosure of examination reports), although such information is necessary for effective market discipline. Banks should also be required to file an updated report when material changes occur that are not reflected in the inost recent report. See id. at 45,378-79 (proposing use of current reports, which would provide information on certain material changes when they occur).

203. For a discussion of the four classifications of loans, see supra note 40 . Banks could be required to einploy statistical techniques used by exanniners to select a sample of loans for review. See, e.g., ComptrolleR's HANDBOoK, supra note 40, at $\$ \S 900.002 .1-.4,900.800 .1$ (OCC's proeedure for use of statistical sampling techniques for examining bank condition).

Reporting of loans by country and by economic sector could be modeled after Guide 3 requirements applicable to bank holding companies. Amendments to Guide 3, 48 Fed. Reg. 37,609, 37,613 (1983) (requirements to be codified at 12 C.F.R. pt. 231). It should include, for each country or economic sector in which there is a minimum level of investment, the amount of loans (in dollars and as a percentage of assets) that fall within each classification category.

204. For an example of this type of data, see $\mathrm{H}$. Wu, Effectiveness of Bank Examiner Loan Criticisms: Some New Evidence 1, 10-13 (1977) (unpublished paper subinitted to the OCC) (on file with author) (study of subsequent history of classified loans over a threc-year period).

205. See generally 50 Fed. Reg. 45,372, 45,374-79 (proposed Oct. 30, 1985) (describing contents of OCC's proposed disclosure reports). 
accountant's opinion on the accuracy of the annual report on bank condition. ${ }^{206}$

Banks should be required to perform their own internal exaininations of their asset portfolios and release that data, along with certain other required information, using uniform reporting formats. Banking regulators could clieck the accuracy of these reports in the course of bank examinations and througli random checks outside of the normal examination process. ${ }^{207}$ Disputes over the accuracy of figures could be resolved informally or, if necessary, through an enforcement action. Alternatively, a procedure miglit be establisled enabling the supervising agency to issue a notice, reporting its estimates and stating that its investigatory findings conflicted with the bank's reported figures. ${ }^{208}$ Uninsured depositors could be allowed a private remedy for any losses against the directors and accountants of an insolvent bank based on fraudulent reports. ${ }^{209}$

\section{Benefits of a Mandated-Disclosure Regime}

A mandated-disclosure regime would be beneficial as long as the disclosed information can predict accurately bank-asset quality. Uninsured depositors could use the composite data, sucli as the percentages of loans classified as substandard, doubtful, and loss, to compare the susceptibility of different banks to loan losses. Studies of federal bank examiners' loan classifications docuinent the ability of exaniners to identify and gradate poor-quality loans as a group. ${ }^{210}$ Although the methodolo-

206. See id. at 45,375 (describing narrative section of proposed annual report). The requirement that only the annual report be certified by accountants is consistent with the OCC's rules for audited financial statements. E.g., compare 12 C.F.R. $\S \S 11.102$ (dd), .390 form F-2, item 8, .910 (1986) (annual reports must include financial statements comporting with subpt. I of pt. 11, which requires inter alia that they be certified), with 12 C.F.R. $\$ \S 11.392$ form F-4, item 1, .917(a)(1) (1986) (quarterly reports must include interim financial statements which need not be certified).

207. Civil fines could be levied against banks and their auditors for incorrect classification of loans. Although subjective evaluations of loans will not be identical, the banking regulators could specify "tipping" factors, whose presence would require a certain classification. The consistency of examiners' classifications with the incidence of defaults in the classification groups, see infra note 210 , suggests that it would be possible to develop a statistieal approach for detecting banks' whose classification of loans are consistently understating lending risks.

208. Banks probably would not be entitled to a hearing prior to the release of investigatory findings. See infra text aceompanying note 250 .

209. This remedy might be modeled after that in section 36(b) of the Investment Company Act, 15 U.S.C. $\S 80 \mathrm{a}-35(\mathrm{~b})$ (1982). Just as a security holder can sue the directors or investment adviser of the mutual fund to recoup money for the pooled fund, see Daily Income Fund, Inc. v. Fox, 464 U.S. 523 (1984) (fund shareholders have a statutory right to enforce fiduciary duty of fund investment adviser), an unsatisfied, uninsured depositor could suc the failed bank's directors or accountants, with any recovery returned to the bank for distribution to uninsured depositors. The receiver of the bank also could be given standing to sue.

210. A study of national bank examiner loan classifications found that $36.5 \%$ and $61.8 \%$ of the loans classified as substandard and doubtful, respectively, became losses, in part or total, or remained classified after three years. $H$. Wu, supra note 204 , at 7,11 . This study used a stratified 
gies of these studies have been criticized, ${ }^{211}$ the studies agree that the incidence of loan losses increases with the severity of the classification. The availability of examination-type data, combined with publicly available call data, would improve depositors' ability to identify near-insolvent banks. ${ }^{212}$ Under a mandated-disclosure regime, large depositors would have the information necessary to make informed decisions about where to place their funds.

Disclosure of information that indicates higher risk in certain banks would affect the price those banks pay for deposits. It is unnecessary for all or most members of the public to review the disclosed information, however. To effectuate inarket pricing it is only necessary that large, uninsured depositors use the data. As already discussed, while "a portion of the public, very sinall perhaps im terms of number but large in terms of the funds it controls," already used the data currently disclosed, they lacked information on loan quality. ${ }^{213}$ Where institutional imvestors judge a bank to involve greater risk, they would demand higher interest rates from that bank. For example, after the recent decline in oil prices, banks with large amounts of energy loans have had to offer higher returns to attract large depositors. ${ }^{214}$ Consistent with that experience,

random sample of 194 banks out of a population of 1390 national banks in five regions, including industrial and rural areas. $I d$. at 5 . While the author noted that increased loss experience expectedly increased with doubtful loans, $i d$. at 14 , he did not explain the unexpected similarity in the outcome of substandard and other loans especially mentioned (OLEM) classifications.

A study of loans liquidated by the FDIC upon taking over banks showed loss percentages of $19 \%, 37 \%, 56 \%$, and $70 \%$ of dollar value for loans considered unclassified, substandard, doubtful, and loss, respectively. FDIC Div. of Liquidation, Evidence on the Ultimate Loss of Adversely Classified Loans 3 (1976) (unpublished paper) (on file with author): The losses shown were adjusted by calculating them on a bank-by-bank basis, so that a few banks would not skew the outcoine. Id. at 2 . The loss figures may be higher than similarly classified loans in solvent banks, since they were from banks that failed. In these situations, inanageinent might be less capable of collecting loans, and, once a bank fails, debtors may avoid repaying loans. Id. at 3-4.

A three year study by the FDIC found loan-dollar loss rates of $9.8 \%, 47 \%$, and $73 \%$ for loans classified substandard, doubtful, and loss, respectively. FDIC Div. of Bank Supervision, The Classified Commercial Loan Survey: A Study of the Performance and Disposition of Adversely Classified Loans 1 (Aug. 30, 1977) (unpublished paper) (on file with author).

Differences in the percentage values are likely due to the differences in management's ability to correct identified problem loans. Also, the differences in percentile figures between the Wu study and the two FDIC studies may be explained by the fact that $\mathrm{Wu}$ based his figures on loan numbers instead of loan dollars.

211. See Gilbert, supra note 74 , at $74-75$ (while conceding that "a number of studies have evidenced their value in predicting risk in bank loan portfolios," it concludes that such studies (1) are limited by the lack of rigorous statistical testing and (2) failed to test for statistical siguificance).

212. Bovenzi, Marino, \& McFadden, Commercial Bank Failure Prediction Models, Econ. Rev., Nov. 1983, at 14, 16-21. The authors conclude that "[g]enerally, including exain data improves the classification accuracy of a inodel." Id. at 20.

213. FDIC, supra note 58, at IV-5; see supra notes 76-77 and accoinpanying text.

214. Some [southwestern] banks are negotiating higher rates and other terms to lure deposits. One Texas money manager says that as recently as a inonth ago, the banks were refusing to negotiate a slightly higher interest rate for a large deposit. But since inany Texas banks were downgraded by investor rating services, "now, all of a sudden, they are 
studies have shown that the CD interest rate is "tiered." Those banks that are considered by market participants to be riskier than the norm are required to pay more for $C D$ funds. ${ }^{215}$ The prices of other uninsured liabilities, such as bankers' acceptances, commercial paper, and federal funds, have on occasion reflected risk considerations. ${ }^{216}$ Other uninsured depositors, observing that institutional investors were receiving higher imterest rates, would demand the same rates or move their funds to banks where they could receive the same interest rates as larger investors. ${ }^{217}$

In addition, a mandated-disclosure regime would improve the safety and soundness of the banking system. Those banks taking extra risks would have to pay for doing so. The higher cost for funds would diminish the current subsidy of bank risk taking and increase the efficiency of those decisions. This risk-based market pressure would encourage banks to prevent classified loans from actually becoming losses. For example, the market would reward those banks capable of preventing loans classified as doubtful froin becoming losses by demanding a smaller premiuin when future doubtful loans are revealed. Uninsured funds would be less volatile, since depositors would choose banks witl compatible risk tastes. Therefore, the incidence of superrisk, loss of confidence, and bank runs should be less frequent. ${ }^{218}$ Rumors would have less impact, since they

willing to negotiate," the money manager says. "They are offering to write the certificate and give you something extra."

A few banks are offering premiums of as much as half a percentage point above market rates, which some banking experts say is highly unusual-and very costly. Apcar, supra note 81, at 2, col. 2.

215. For four months after the failure of Penn Square, Continental Illinois had to pay a CD rate 100 basis points higher than that of the other money-center banks. Gilbert, supra note 74, at 72. When Franklin National failed, depositors charged regional banks a CD rate 25 basis points higher than money-center banks. Id. at 71.

216. For example, the spread between the T-bill rate and interest rates for bankers' acceptances, commercial paper, and federal funds increased after Franklin National received a negative examination a year before its failure and peaked at the time of its failure. Stover \& Miller, Additional Evidence on the Capital Market Effect of Bank Failures, F1N. MGMT., Spring 1983, at 36, 38-40. Franklin National itself was unable to borrow federal funds from many banks fivc months prior to its failure, when the Federal Reserve indicated that the bank was involved in a retrenchment program. M. STIGUM \& R. BRANCH, JR., supra note 2, at 192-93.

Once the information on bank condition is released, it will also be available to shareholders, who might act as an additional source of market discipline. See supro note 76. But see supra text accompanying notes $162-68$.

217. See Gilson \& Kraakman, The Mechanisms of Market Efficiency, 70 VA. L. REv. 549, 57279 (1984) (discussing mechanisms for transmission of information to investors, with behavior of large investors as one mechanism).

218. Of course, risk-prone depositors who lent to high-risk banks would still run, if those banks were to fail. Given that risk is a cost for most individuals, see supra note 86 , it is unlikely that many people would be willing to lend funds to banks at a low enough rate to make the high-risk strategy profitable. A person of average risk aversion would require a risk premium large enough to compensate for the extra risk of failure. Thus, in equilibrium, the risk-adjusted return for investing in a risky bank would equal that for a sound bank, removing the profit motive for a bank to follow a risky-asset strategy. A policy of insulating individual bank failures, see supra text accompanying 
could be checked readily against data. Finally, runs would be less likely to spread because banks would be judged on their own risk features and not a perceived average-risk level.

A inandated-disclosure regime would have the additional benefit of removing the elements of secrecy froin the banking systein. The nondisclosure regime reflects an incorrect premise that the public has no interest in knowing the actual condition of individual banks. ${ }^{219}$ Because the public deals with banks and other financial intermediaries on a regular basis, it has a legitimate interest in the activities of banks and the regulation of the banking system. Like the FOIA, a mandated-disclosure regime would facilitate the achieveinent of the informed-citizenry ideal. ${ }^{220}$

notes 189-92, should enable the banking system to remain stable despite failures of the few high-risk banks.

219. This view was best expressed by then Chief Counsel of to the Comptroller of the Currency, Robert Bloom, during the 1964 hearings on FOIA:

Senator Long. I gathered rather generally from your statement a while ago that in your judgment there is no information and no inaterial in the Office of Comptroller of the Currency that should be made available to the public or to the news media.

Mr. Blooin. I cannot think of any [bank] records of our Office the release of which would benefit the public in the sense of the ones wlio are concerned with a particular bank ....

APA Hearings, supra note 26, at 184. But see Blooin, supra note 27, at 724-26 (noting that two years later the OCC began disclosing information on contested branch and new-bank applications).

The stateinent submitted by the OCC at the hearings on FOIA went so far as to say that the public did uot even have an interest in knowing the explanations of the information required for preparing examination reports:

The requireinent for publication of "instructions as to the scope and contents of all papers, reports, or exaininations" would serve no useful public purpose inasinuch as the bankers and our exaininers are fully familiar with our forms, and, in our view, inembers of the general public would have no interest in the form of these documents.

APA Hearings, supra note 26, at 190.

220. The House Report accompanying FOIA argued that "[a] denocratic society requires an informed, intelligent electorate, and the intelligence of the electorate varies as the quantity and quality of its information varies. ... [FOIA] provides the necessary machinery to assure the availability of Government inforination necessary to an inforined electorate." H.R. REP. No. 1497, supra note 29, at 12, reprinted in 1966 U.S. CODE CONG. \& AD. NEws at 2429. Professor Davis has pointedly noted the inconsistency of exenption 8 with the philosophy of FOIA: "We must be extremely careful or the facts about our financial institutions inight becoine known! We want the public to know the truth about almost all our institutions, but not about our financial institutions!" Davis, The Information Act: A Preliminary Analysis, 34 U. CHI. L. REv. 761, 801 (1967).

The democratic ideal of FOLA, however, is equally applicable to the banking systein. The FDIC has drawn the link between the informed-citizenry model and the market-discipline benefits from disclosure:

There are few, if any, institutions which so profoundly affect the public interest, but are so universally inisunderstood, as banks. In the FDIC's view, the public has a need and right to make its own judgments with respect to banks. Moreover, it is in the long-run best interests of banking to coinbat the existing mystique and misunderstanding.

FDIC, supra note 58, at IV-7. 


\section{Possible Costs of a Mandated-Disclosure Regime}

The benefits of a mandated-disclosure regime would not come without costs. The question is whether the benefits of disclosure would outweigh the adverse effects. While some banks would lose funds even with a suitable phase-in period, increased systemic stability and inore efficient risk taking may well warrant the abandonment of the "peaceful" yet unstable status quo. This conclusion, however, cannot be reached without examining the costs of disclosure. This subsection considers four concerns about the use of disclosure to regulate banks. Opponents argue that it will (1) threaten the safety and soundness of the banking system, (2) violate privacy expectations, (3) harm the coinpetitive position of federally regulated banks vis-à-vis other financial imstitutions, and (4) hinder effective banking regulation.

\section{a. Safety and Soundness Concerns}

The major justification for the nondisclosure regime is the fear that disclosure of examination-type data would undermine public confidence in the banking system. ${ }^{221}$ The fear that informed depositors will run against unsound banks and misinformed depositors will run against sound banks ${ }^{222}$ assumes both that depositors are unable to correctly analyze such data and that the banking industry is peculiarly unstable. The first assumption, besides contradicting the rationale of FOIA, ${ }^{223}$ is contrary to the realities of the banking regulatory system. Federal deposit insurance already insulates banks froin runs by those depositors who arguably would be most likely to either misinterpret the disclosed information or rely on sensationalistic inedia accounts. ${ }^{224}$ The threat that uninsured depositors ${ }^{225}$ might withdraw their money or refuse to roll it

221. See supra notes $27-28$ and accompanying text.

222. This fear has often been expressed in paternalistic tones. E.g., APA Hearings, supra note 26, at 186 (testimony of Robert Bloom, Chief Counsel, OCC) (arguing that release of information to "an unsophisticated public could, through misunderstanding, undermine confidence"). For a recent statement of this view, consider the comment to OCC's release on disclosure by the president of one Nebraska bank: "Further disclosure ... will only serve to confuse and frighten [depositors], and like a herd of cattle on a dark and stormy night they could seize upon innocuous information which they did not understand as a catalyst for a sudden and explosive stampede." Letter from John H. Morehead, President of the Richardson County Bank and Trust Co., to the OCC (July 31, 1984) (on file with author).

223. See supra note 220.

224. Those depositors would be the ones relying on a withdrawal strategy, namely small depositors. See supra text accompanying note 72. Assuming the FDIC quickly pays off insured deposits, insured depositors should not run, unless they do not understand this protection. See, e.g., Dietz, Customer Confusion on Federal Insurance, San Francisco Examiner, June 30, 1985, at D1, col. 2 (run by insured depositors against FDIC-insured bank, where depositors, most of whom were Chinese-American immigrants, did not understand that their deposits were guaranteed by the federal government).

225. The presumption that uninsured depositors will pursue a monitoring strategy depends on 
over exists currently. Under a mandated-disclosure regime, however, this result would be premised less often on rumors and more often would reflect a focused, informed source of market discipline. As for the assuinption of mdustry instability, commercial banks can respond to this vulnerability by producing confidence. This response would be better strengthened by disclosure rather than by the present overrehance on $\mathrm{X}$ confidence. $^{226}$

The bank regulatory system's goal of maintaining a stable banking system is distinct froin a goal of preventing the failure of any and all banks. $^{227}$ While individual banks whose assets deteriorate will be inore susceptible to runs, the risk of failure is inherent in a functioning market system and serves the useful purpose of weeding out mefficient firms. The urique danger of the banking systern that one firm's failure will trigger the failure of other firms actually will be reduced under a mandateddisclosure regime because depositors will not group together sound and unsound banks. ${ }^{228}$ Given adequate disclosure, informed depositors would pressure banks to manage inore carefully their lending and collection processes, which should thereby reduce the number of problein banks. ${ }^{229}$

The fact that individual, even large, banks might fail does not justify the continued rehiance on a nondisclosure regime. Most banks should avoid failure because of depositor discipline. Correspondent banks will possess sufficient information to effectively inomitor weak banks and could internalize the costs of their potential failure in the iritial pricing of correspondent services. ${ }^{230}$ This will discipline large banks and reduce

whether the deposit insurance has been set at an optimal level. Recall that deposit insurance should be set equal to the point where a monitoring strategy becomes cost beneficial. See supra note 114 . The use of a inodified payout would cause this figure to be adjusted upwards, since presumably less of the deposit would be at risk. Furthermore, uninsured depositors need not analyze the information, but can simply Inonitor the behavior of institutional investors. See supra text accoinpanying note 217 .

226. See supra text accompanying notes 136-51.

227. BLUEPRINT, supra note 15, at 35 ("The goal is not a systein in which financial firms never fail, ... but rather one in which failures that do occur do not impair the stability of the financial system as a whole.").

228. See supra text accoinpanying note 143 .

229. The FDIC justified its proposal to disclose the names of banks against whoin it has begun an enforcement action with similar reasoning:

Should a custoiner be averse to the risk of a continuing relationship with a bank against which a statutory enforcement action has been undertaken, the selection of a new bank or banks with whoun to conduct business should inure to the benefit of well managed competing institutions. Thus [it] ... should have the long range effect of strengthening the industry.

Disclosure by the FDIC of Statutory Enforcement Actions, 50 Fed. Reg. 7220, 7221 (proposed Feb. 21, 1985), adopted in 50 Fed. Reg. 20,609 (1985), postponed by 50 Fed. Reg. 52,557 (Dec. 29, 1985).

230. The ripple effects of a bank failure spreading to correspondent banks and those selling federal funds is potentially great. See Continental Illinois Hearings, supra note 54, at 418, 434-35 (staff report of House Subcomm. on Financial Institutions Supervision, Regulation and Insurance) 
the amount of correspondent-bank funds in weak banks, both of which make it less likely that the failure of a large bank will threaten to undermine the soundness of other banks. Also, the availability of lender-oflast-resort facilities to banks with sound asset portfolios but facing temporary liquidity shortfalls should prevent a banking panic from spreading to sound banks. ${ }^{231}$ This safety net should reduce the risk of a sound bank failing due to occasional depositor overreaction or due to the loss of liquid funds when another bank it had dealt with fails. Thus, a mandateddisclosure regime may make weak banks more susceptible to runs, but failure should be limited to inefficient banks and greater systemic stability should result.

\section{b. Privacy Concerns}

Opponents of disclosure of examination-type data claim that it will violate principles of privacy. ${ }^{232}$ The release of composite data on asset quality, however, should not threaten the privacy of either borrowers or bank employees. Requiring banks to disclose this data does not implicate constitutionally protected privacy interests of the banks, because "[a] substantial claim of privacy or confidentiality cannot be maintained with respect to the financial records of an orgamized collective entity."233

(reporting that Continental Illinois had uninsured funds from banks in a number of states, with the exposure of 66 banks in amounts greater than $100 \%$ of their equity capital and the exposure of another 113 of between $50 \%$ and $100 \%$ of their capital). If those banks know that de facto deposit insurance will not be available, the amounts they demand for the use of their funds will reflect risk and serve to discipline risk taking by the borrowing bank. The FDIC's recognition of the benefits attainable through rehance on market discipline exerted by correspondent banks is implicit in its recent study of proposals to exclude financial institutions from deposit insurance coverage. 49 Fed. Reg. 26,809, 26,809 (1984). A suitable transition period before mandated disclosure becomes effective would allow for banks to adjust to reflect the new risks.

231. See supra text accompanying notes 189-92.

232. See, e.g., APA Hearings, supra note 26, at 184, 186 (testimony of R. Bloom, Chief Counsel, OCC) ("The examination reports contain information concerning the personal finances of everyone in the community with whom the bank does business. Sueh information has traditionally been considered as private as one's own home and not to be made public without due process of law." Id. at 186.).

233. Bellis v. United States, 417 U.S. 85, 92 (1974) (holding fifth amendment privilege against self-incrimination inapplicable to records of a three-partner law firm, because "corporate records do not contain the requisite element of privacy or confidentiality essential for the privilege to attach"); California Bankers Assn. v. Shultz, 416 U.S. 21, 55, 66-67 (1974) (no fourth or fifth amendment violation in forcing banks to comply with transaction reporting requirements of Bank Secrecy Act of 1970).

In United States v. Morton Salt Co., 338 U.S. 632 (1950), which held that salt producers and their association must comply with an FTC order to file reports detailing their compliance with an earlier cease and desist order, the Court stated:

$[N]$ either incorporated nor unincorporated associations can plead an unqualified right to conduct their affairs in secret. ...

While they may and should have protection from unlawful demands made in the name of public investigation, ... corporations can claim no equality with individuals in the enjoyment of a right to privacy. ... They are endowed with public attributes. They have a 
Although the identity of certain large borrowers might be inferred from the available composite data, ${ }^{234}$ these borrowers would probably be sovereigns or large companies, which likewise do not possess substantial privacy interests in such data.

\section{c. Competitive-Effects Concerns}

Banks and regulators assert that disclosure of examination-type data would prevent federally regulated banks from competing effectively with other banks and financial intermediaries. ${ }^{235}$ For example, disclosure of aggregate classified loans by sectors might reveal management's lending strategy and the potential profitability of lending to that sector. ${ }^{236}$ While individual banks might lose the monopoly profits from exclusive development of a lending market, competitive pressures from other banks and financial intermediaries would prevent banks from abandoning efforts to find new markets. ${ }^{237}$ Banks would still gain the advantage of being the first lender in the field and would still require new markets for generating

collective impact upon society, from which they derive the privilege of acting as artificial entities. The Federal Government allows them the privilege of engaging in interstate commerce. Favors from the government often carry with them an enhanced measure of regulation. ... Even if one were to regard the request for information in this case as caused by nothing more than official curiosity, nevertheless law-enforcing agencies have a legitimate right to satisfy themselves that corporate behavior is consistent with the law and the public interest.

Id. at 652 (citations omitted); see Greenawalt \& Noam, Confidentiality Claims of Business Organizations, in Business Disclosure: Government's NEed To KNow 378, 380-88 (H. Goldschmid ed. 1979) (arguing that businesses' claims of confidentiality of records must be premised on grounds such as economic efficiency, only raising privacy concerns when "claims to confidentiality ... rest ultimately on the claims of privacy of the individuals concerned," id. at 382); $c f$. Ruckelshaus v. Monsanto Co., 467 U.S. 986 (1984) (holding businesses could be required to submit data on the effects of pesticides as a condition of doing business); United States v. Miller, 425 U.S. 435, 442-43 (1976) (depositor had no constitutionally recoguized fourth amendment right to prevent the bank, acting pursuant to government subpoena under the Bank Secrecy Act, from disclosing transactional records voluntarily conveyed to it by the depositor).

234. For example, composite data on classified loans might be displayed by individual country, as is provided for in the SEC reporting requirements for loan classifications. See supra note 52 and aceompanying text. This might indicate the quality of loans to a sovereigu borrower where it is known that inost loans to that country are to public entities.

235. See, e.g., APA Hearings, supra note 26, at 186 ("[Examination reports] contain detailed information concerning every aspect of the busmess of the bank. It would be grossly unfair and in violation of basic principles of competition to make this information available to competitor banks."); FDIC, supra note 58, at IV-1 (acknowledging "competitive equity" concerns, if disclosure is not required of S\&L's).

236. See supra note 200 and accompanying text. Similar arguments have been made regarding the effects of information disclosure in other industries. See, e.g., Casey, Marthisen, \& Moss, The Economic Impact of the Freedom of Information Act, 1984 AIPLA Q.J. 76, 84-89 (arguing that a shipper's export declarations, which contain detailed information on products shipped and, inferentially, marketing strategy, are "circumstantially relevant business information," and disclosure could aid competitors in ascertaining those market opportunities, thus reducing the benefits of the initial research effort).

237. For discussion of the increased competitive pressures, see supra notes $142 \& 170$ and text accompanying note 127 . 
profit. ${ }^{238}$ Thus, banks probably would continue to develop these new markets.

Although mandated disclosure should result in banks with risky assets paying more for their funds, this result is beneficial. The purpose of a mandated-disclosure regime is for the market to exert discipline by charging a risk premium, thereby forcing banks to choose efficient levels of risk. Banks that are at least as healthy as they were judged to be in the predisclosure market should experience no increase in the cost of funds. Indeed, because investors would have assurances of their safety they inay face lower costs.

Disclosure probably will not hurt the ability of federally regulated banks to compete with non-FDIC-insured depository institutions. Such institutions that are healthier than the average bank would have an imcentive to disclose similar information, in order to avoid paying interest rates higher than those paid by banks of comparable riskiness. The previously discussed problems of disuniformity and misinformation ${ }^{239}$ probably would prevent depositors from comparing banks with financial institutions not covered by this mandated-disclosure regime. Less healthy non-FDIC-insured depository institutions would have an incentive to prevent comparisons with healthy banks. They would, however, want to disclose seemingly favorable data, in order to distinguish themselves from other depository institutions thought to be in serious financial difficulty. ${ }^{240}$ Given the financial condition of the thrift industry, ${ }^{241}$ concerns over the solvency of FSLIC, ${ }^{242}$ and the recent discrediting of state-

238. "It is important to put this reduction of new information in its proper perspective. Most information must be produced in any case, because a company's operations require it." Greenawalt \& Noam, supra note 233, at 411 . Thus, in the case of shipper's export declarations, see supra note 236 , it is doubtful that firms would abandon a market in order to avoid notifying its competitors of its existence.

239. See supra text accompanying notes 197-99. The fact that many of the recent problems of S\&L's are due to "imprudent real estate lending, rather than losses on interest-rate spreads," " Thrift Portfolios Of Mortgages Rise Above Book Value, Wall St. J., Jan. 2, 1986, at 2, col. 4 (w. ed.) (quoting Eric Hemel, chief economist, FHLBB) [hereinafter cited as Thrift Portfolios], would seem to argue $\mathrm{m}$ favor of instituting mandated disclosure after a suitable transition period.

240. See supra text accompanying notes 198-200.

241. See, e.g., Thrift Portfolios, supra note 239, at 2, col. 4 (reporting that "[r]esidential mortgages held by the nation's thrifts have a higher market value than book value for the first time since 1979" due to falling interest rates but the improvement "will have a negligible effect on the roughly one-third of all thrifts at or near insolvency").

242. E.g., S\&Ls Operated by Host Managers Continue to Deteriorate While Insurance Fund Woes Worsen, FSLIC Director Says, [July-Dec.] WASH. FIN. REP. (BNA), at 802 (Nov. 25, 1985) (reporting that the FSLIC will have to acquire an additional $\$ 7$ billion of bad assets froin 30 failing thrifts in management consignment programs, raising its total holdings to $\$ 10$ billion, yet it only has $\$ 3.2$ billion of unobligated reserves). Peter Stearns, the recently resigned director of the FSLIC, noted that if during 1986 the FSLIC were to provide assistance or arrange a merger of the 30 thrifts in the inanagement consigument program, "the fund would show a negative net worth." Id. at 804. Moreover, about 360 other thrifts, insolvent under generally accepted accounting principles, will not return to profitability without assistance. Id. 
sanctioned, private deposit insurance, ${ }^{243}$ uninsured depositors probably would choose a bank whose disclosures showed it to be sound over a thrift of unknown condition, all other things equal. Concerns over effective depositor discipline and efficient risk taking warrant uniform disclosure requirements for all deposit-taking institutions, but the absence of such a coinprehensive approach would not competitively disadvantage sound banks.

Mandated disclosure probably would not weaken the competitive posture of U.S. banks in international markets. The disclosure of composite data on classified loans conceivably might cause some governments to shun U.S. banks, because the disclosure of such information might enable the determination of their financial condition. ${ }^{244}$ However, those affected would be sovereign borrowers who are experiencing serious difficulty meeting their loan obligations and would need to contimue relationships with U.S. banks in order to restructure their loans. Recent experience has shown that foreign banks are not immune to excessive risk taking and failure. ${ }^{245}$ U.S. banks that adjust to the new market discipline from disclosure should not find their competitive positions weakened. Indeed, they nay find their positions strengthened, because foreign depositors would know that they are sound banks, yet lack comparable information about competing foreign banks.

\section{d. Regulatory-Effectiveness Concerns}

Concerns that a inandated-disclosure regime would hamper effective regulation of banks ${ }^{246}$ do not seem to be well-founded. Such arguments

243. See supra notes 55-56 and text accompanying notes 115-16.

244. See supra note 234 and accompanying text.

245. "The near failure of the National Westminster Bank in England and the failure of the German bank Bankhaus Herstatt in 1974 were clear signs that the European Bank regulatory apparatus was also not equipped to handle the new challenges of international banking." H.R. REP. No. 175, supra note 60, at 32, reprinted in 1983 U.S. CODE CONG. \& AD. NEwS, at 1915; see M. STIGUM \& R. BRANCH, JR., supra note 2, at 390, 392-94 (discussing banking crises in Canada and Italy); cf. Note, supra note 173, at 446 (arguing that U.S. regnlators should avoid "undue preoccupation with the regulatory policies of other industrialized nations" leading to a " "race to the bottom'").

While a coordinated international regulatory approach would have benefits for bank regnlation, see Joint Memoranduin, supra note 174, at 31, it should not be viewed as a sine qua non for mandated disclosure because there is no reason for believing that disclosure will weaken the competitive posture of sound U.S. banks in the international market.

246. APA Hearings, supra note 26, at 186 (statement of R. Bloom, Chief Counsel, OCC) ("The mere possibility that the types of information just discussed would be available to its competitors and the general public would make bankers most reluctant to cooperate with our examiners and seriously hamper the Comptroller in the exercise of his assigned duties."); $i d$. at 549 (submitted statement of Am. Bankers Ass'n) (argning that because bank examiner's reports include conclusions and opinions which are felt to be subjective, bankers are willing to cooperate due to understanding of confidentiality, but if the reports were disclosed, "freedom of expression on the part of both the bankers and the exaininer would be destroyed"). 
presume that bank management has the option of withholding information and cooperation from the regulatory authorities. ${ }^{247} \mathrm{~A}$ mandateddisclosure regime denies the exercise of this option with impunity. The benefits from increased market discipline will more than compensate for the imcreased cost due to the reduced cooperation between banks and regulators. $^{248}$ Banks, fearing disclosure of poor-quality loans, will be more diligent in making and collecting loans.

Banks might contest examination results more frequently if this data were used to monitor quarterly disclosures of asset quality. ${ }^{249}$ Such examinations, however, are only supervisory actions or investigations and would not entitle banks to adjudicatory hearings. ${ }^{250}$ Furthermore, requiring banks to disclose certified evaluations of asset quality that were prepared internally would not rise to the level of an agency adjudication requiring hearings and due process. ${ }^{251}$ Actual contested actions might occur if and when banks and their accountants were suspected of releasing false reports of asset quality. Even then, however, banks would have an incentive to settle their differences with the regulators to avoid potentially severe sanctions. ${ }^{252}$ For those relatively few instances where settle-

247. See Consumers Union v. Heimann, 589 F.2d 531, 541 (D.C. Cir. 1978) (Wright, C.J., concurring) (noting the OCC's ability to conipel disclosure aud assess banks for the costs involved and concluding that, although a goal of promoting cooperation can be desirable, "it can if overcmphasized be flatly inconsistent with the very purposes of regulation itself").

248. Statements of the FDIC support this conclusion:

Adoption of this policy will not only promote market discipline, but will also enhance the FDIC's supervisory efforts. Facing the specter of disclosure, bank manageinents may be less likely to engage in activities which are unsafe or unsound. . . . [A]wareness of notices and final orders should provide the market, in concert with the FDIC, with the opportunity to exert pressure on banks to eliminate the unsafe and unsound practices and conditions within their control and to attract and retain competent personnel to properly manage bank affairs.

Disclosure by the FDIC of Statutory Enforcement Actions, 50 Fed. Reg. 7220, 7224 (proposed Feb. 21, 1985), adopted in 50 Fed. Reg. 20,609 (1985), postponed by 50 Fed. Reg. 52,557 (Dec. 24, 1985); see supra text acconipanying notes 213-17.

249. Contesting of examination conclusions could hinder speedy examinations. See APA Hearings, supra note 26, at 193 (testimony of R. Blooin, Chief Counsel, OCC) (arguing that the OCC "would have to close up shop" if it used even an informal procedure to hear complaints about examinations).

250. "The critical process in the federal control of banking is the supervising power, not adjudication or rule making. The supervising power is not and probably cannot be surrounded by procedural safeguards in formal hearings, and it is largely immune from the check of judicial review." K.C. Davis, Administrative LAw Treatise § 4.04, at 251 (1958); see APA Hearings, supra note 26, at 182 (describing bank supervisory practices in approving an application to charter a new bank, Robert Bloon, Chief Counsel, OCC, states: "There is very seldoin a disputed adjudicatory fact involved. They are much more in the nature of investigations."); K.C. DAvis, supra, at $\$ 4.04$, at $247-49$.

251. Cf. supra note 233 (reviewing case law requiring businesses to disclose data required by regulators to further the public interest). The reports would represent the bank's and its auditor's judgments of its condition and would not involve agency action.

252. Professor Davis provided as an example of this common behavior the examiner's enforcenent of the Federal Reserve's prohibition of "undue use" of bank credit for speculative 
ment efforts fail, public notice of civil enforcement actions would be valuable for promoting general deterrence and correcting false perceptions of the quality of examined banks. ${ }^{253}$ There is no reason to believe thiat these regulatory costs would be any greater than those of otlier regulated industries nor that they would prevent effective regulation.

\section{CONCLUSION}

This Comment has suggested that the banking regulatory systein needs to appreciate the importance of confidence in the decisions of depositors and the benefits from using information to provide for that confidence. A mandated-disclosure regime would increase confidence in banks and lead to a more stable systein. Such a regime would enable depositors to select banks offering risks and returns most compatible with their preferences. The flow of uninsured depositors' funds to well-managed banks would thus create a stable, disciplined market.

A mandated-disclosure regime could sever the link between inefficient risk taking by banks and excessive and increasingly speculative conduct in the econoiny by banks and their borrowers. Inefficient risk taking by banks fuels the speculative conduct of other economic actors, whicl1 feeds back into the banking systein, weakening banks, thus continuing the cycle. ${ }^{254}$ The speculative nature of banking combined witl the freedoin imparted by enforced nondisclosure practically guarantee inefficient bank risk taking, which leads to excessive speculation througlout the economy. In today's financial environment, "[t]he lessons of history, to the effect that unregulated or inadequately regulated financial institutions and markets tend to generate unstable financial relations, [are] forgotten."255 Unless clianges are made in the regulatory system, we seem predestined to reexperience speculative excesses fueled by inefficient bank

behavior. Examiners enforcing this policy inform bank management of items they feel require correction and

[a] bank which is inclined to disagrec does not typically stand on its supposed rights and defy the [Federal Reserve] to start a formal proceeding; suspension is too drastic a remedy for the bank to risk. The bank deals informally with the [Federal Reserve's] representatives until some mutually satisfactory solution is worked out. Adjudication gives way almost entirely to supervision. The admmistrative mainstay is prevention rather than cure or punishment. The sanction is not the power of suspension but the power of instituting proceedings.

K.C. DAVIS, supra note 250 , at $\S 4.04$, at $248-49$.

253. These actions would be analogous to enforcement actions, from which the FDIC will disclose the names of defendant banks when fiual orders are issued. See supra text accompanying note 179.

254. See Minsky, supra note 1, at 145-47 (bidding up the price of capital assets and increasiug leveraged investment is due to the development of a "euphoric" " economy, noting that "success breeds a disregard for the possibility of failure").

255. Minsky, Financial Instability, the Current Dilemma, and the Structure of Banking and Finance, in Staff of Senate Comm. on Banking, Housing and Urban Affairs, 94TH Cong., Ist Sess., Compendium of Major Issues in Bank Regulation 310, 311 (Comm. Print 1975). 
risk taking. A mandated-disclosure regime offers a way out of this cycle by connecting the costs of risk taking with the risk-taking decision.

Albert J. Boro, Jr.*

* A.B. 1982, M.P.P. 1985, University of California, Berkeley; third-year student, Boalt Hall School of Law, University of California, Berkeley. 